\title{
How Does Risk Management Influence Production Decisions? Evidence from a Field Experiment
}

\section{Citation}

Cole, Shawn, Xavier Gine, and James Vickery. "How Does Risk Management Influence Production Decisions? Evidence from a Field Experiment." Harvard Business School Working Paper, No. 13-080, March 2013.

\section{Permanent link}

http://nrs.harvard.edu/urn-3:HUL.InstRepos:10647828

\section{Terms of Use}

This article was downloaded from Harvard University's DASH repository, and is made available under the terms and conditions applicable to Open Access Policy Articles, as set forth at http:// nrs.harvard.edu/urn-3:HUL.InstRepos:dash.current.terms-of-use\#OAP

\section{Share Your Story}

The Harvard community has made this article openly available.

Please share how this access benefits you. Submit a story.

Accessibility 
H A R VAR D

\section{How Does Risk Management Influence Production Decisions? Evidence from a Field Experiment}

Shawn Cole

Xavier Giné

James Vickery

\section{Working Paper}

13-080

March 25, 2013 


\title{
How Does Risk Management Influence Production Decisions?
}

\author{
Evidence from a Field Experiment ${ }^{*}$
}

\author{
Shawn Cole (Harvard Business School) \\ Xavier Giné (World Bank) \\ James Vickery (Federal Reserve Bank of New York)
}

First Version: February 2011

This version: March 2013

\begin{abstract}
Weather is a key source of income risk for many firms and households, particularly in emerging market economies. This paper studies how an innovative risk management instrument for hedging rainfall risk affects production decisions among a sample of Indian agricultural firms, using a randomized controlled trial approach. We find that the provision of insurance induces farmers to shift production towards higher-return but higher-risk cash crops, particularly amongst moreeducated farmers. Our results support the view that financial innovation may help mitigate the real effects of uninsured production risk. In a second experiment we elicit willingness to pay for insurance policies that differ in their contract terms, using the Becker-DeGroot-Marshak mechanism. Willingness-to-pay is increasing in the actuarial value of the insurance, but substantially less than one-for-one, suggesting that farmers' valuations are inconsistent with a fully rational benchmark.
\end{abstract}

\footnotetext{
*Email: scole@hbs.edu, xgine@worldbank.org and james.vickery@ny.frb.org. We owe a particular debt to K.P.C. Rao for his efforts in managing the field work associated with this study, as well his survey team. Outstanding research assistance was also provided by Fenella Carpena, Lev Menand, Veronica Postal, Jordi de la Torre, and Wentao Xiang. We also thank conference and seminar participants at the University of Wisconsin, UC Davis, FERDI, Harvard Business School, the NBER Universities Conference on Insurance Markets and Catastrophe Risk, European Finance Association meetings, the CEPR/HEC/Tilburg conference on Financial Intermediation and the Real Economy, the World Bank, and the Stockholm School of Economics. We particularly thank our discussants Ulrich Hege, Aprajit Mahajan and Peter Nyberg, as well as Jeremy Tobacman and Petia Topalova for their comments and ideas. Financial support for this project was provided by the Research Committee of the World Bank. Views expressed in this paper are those of the authors alone, and do not necessarily reflect the opinions of the World Bank, the Federal Reserve Bank of New York or the Federal Reserve System.
} 
Risk management and insurance is a key function of the global financial system, and a source of significant financial innovation in recent decades. ${ }^{1}$ This paper studies how access to an innovative retail risk management instrument influences "real" production decisions. We focus on a sample of small agricultural firms in a semi-arid region of India, a setting in which rainfall variability during the monsoon is the primary source of production and income risk. We employ a field experiment approach: a randomly selected treatment group of farmers are provided with a significant quantity of rainfall index insurance at the start of the monsoon, mitigating their exposure to rainfall risk. We then study how this insurance provision influences subsequent production decisions (relative to a control group), such as crop choice and usage of agricultural inputs.

Our empirical analysis relates to a large theoretical literature on the link between incomplete markets and production decisions. In an idealized setting with complete risksharing, production and investment are decoupled from non-systematic income risk. Firms simply invest whenever the net present value of an investment (measured using an economywide aggregate pricing kernel) is positive. Non-systematic risk is generally expected to influence production decisions when markets are incomplete, however (e.g. Froot and Stein, 1998; Rosenzweig and Binswanger, 1993; Bodie, Merton and Samuelson, 1992; Gollier and Pratt, 1996). One prediction of theory is that firms or households subject to uninsurable idiosyncratic risk may shift towards lower-risk, lower-return production activities; this response is dubbed "income smoothing" by Morduch (1995). Firms may also favor production activities whose returns covary negatively (or less positively) with the sources of uninsurable risk (Froot and Stein, 1998).

We test these theoretical predictions amongst a sample of agricultural firms facing a specific source of exogenous, non-systematic production risk -- variation in local rainfall during the monsoon season. Rainfall is cited as the most important source of risk by $89 \%$ of our sample. These local rainfall shocks are, to a first approximation, non-systematic: they are

\footnotetext{
${ }^{1}$ For example, there has been enormous growth in the size and scope of the market for financial derivatives (e.g. credit default swaps, commodity futures, interest rate swaps etc.) used by firms to manage market and credit risk. A second example is the development of the "catastrophe" bond market, that allow for automatic principal forgiveness following the occurrence of a pre-specified set of catastrophe events, such as a hurricane or flood. Securitization is also motivated in large part by the desire to diversify risk.
} 
approximately uncorrelated with global aggregate asset returns. Because farmers have a nondiversified exposure to local weather risk, however, rainfall shocks, and in particular drought, have significant and persistent effects on economic well-being and health for affected households, as shown in previous research studying India and other emerging market countries (e.g. Rose, 1999; Maccini and Yang, 2009; Jayachandran, 2006).

Recognizing the importance of rainfall risk, a number of Indian insurers have in recent years developed innovative retail index insurance products designed to pay out when realized monsoon rainfall is poor. We study a particular policy developed by the private Indian insurer ICICI Lombard. Our analysis builds on a series of field experiments and surveys that we have conducted since 2004 in Andhra Pradesh, India (see Giné, Townsend and Vickery, 2008, and Cole et al. 2013). This previous work has focused on studying the determinants of the demand for rainfall insurance, rather than the impact of insurance on behavior.

Identify the causal effects of insurance provision is typically difficult given that insurance takeup decisions are inevitably correlated with unobserved firm or household characteristics. For this reason, we use a randomized controlled trial (RCT) approach, in which insurance is randomized across farmers. At the start of the monsoon, half the farmers in our sample, the treatment group, were provided with 10 rainfall insurance policies, with a combined market value of approximately Rs. 1000 (equivalent to \$20-\$25 US). This is a significant amount of coverage for our sample; the maximum insurance payout of Rs. 10,000 is equivalent to about $90 \%$ of reported median household savings. The control group was instead promised a fixed cash payment equal to an estimate of the actuarial value of the insurance policy (Rs. 350, or around $\$ 8$ US) to be paid at the same time as insurance payouts. We then study differences in subsequent production decisions during the monsoon between these two groups.

We find that insurance provision has little effect on total agricultural investments, but causes significant shifts in the composition of those investments. In particular, treated households allocate more agricultural inputs (e.g. fertilizer, seeds, land) to the production of the main cash crops grown in the area, castor and groundnut. These two crops produce higher 
expected returns but are more sensitive to deficient rainfall. Insured farmers are more likely to plant cash crops, allocate a larger value of agricultural inputs to these two crops, and also plant more land with cash crops. Quantitatively, the fraction of farmers planting cash crops is 6 percentage points higher for the treatment sample $(\mathrm{p}=0.041)$, or 12 percent (since about half of farmers planted cash crops in the monsoon season we study).

Insurance provision has the greatest effect on production decisions amongst educated farmers, measured either by years of schooling, or an indicator variable for whether the farmer is literate. This heterogeneity by educational attainment is economically as well as statistically significant. Among literate farmers, assignment to the insurance treatment group increases the likelihood of investing in cash crops by 15 percentage points; among illiterate farmers, the treatment effect is indistinguishable from zero. We do not observe any corresponding heterogeneity by household wealth or landholdings.

This empirical evidence is inconsistent with a full risk-sharing benchmark, but is consistent with the predictions of models in which production decisions are in part driven by risk management concerns (e.g. Froot and Stein, 1998). Our results relate to a large literature in development economics on the determinants of investment, growth and capital flows for emerging market economies. The "Green Revolution" introduced high-yield crop varieties, chemical fertilizer and other cultivation practices that tremendously increased global agricultural productivity. Yet, traditional farming practices still predominate in many areas, and take-up of new agricultural technologies remains limited, despite high expected rates of return (Duflo, Kremer and Robinson, 2008; Suri, 2009). Our results suggest that limited insurance against idiosyncratic production risk may be one explanation why firms in developing countries are unwilling to shift towards investments that generate higher returns, but with greater risk. ${ }^{2}$

\footnotetext{
${ }^{2}$ Our results are also related to literature of the effect of climate change on agricultural productivity. Guiteras (2009) uses historic rainfall variation to estimate the impact of weather on agricultural productivity, taking into account farmers' endogenous risk-management strategies. He finds that predicted climate change from 2010-2039 will reduce major crop yields by 4.5 to 9 percent. While rainfall insurance cannot of course affect the climate, it may enable farmers to continue to produce risky crops in the face of increasing climate variability, lessening the real impact of climate change on productivity and incomes.
} 
Our findings also contribute to prior research on financial innovation and financial literacy. The risk management product we study represents an example of a new financial innovation targeted at retail-level customers. In recent years, academics and the public at large have emphasized the costs of financial innovation, associated with predatory behavior by financial intermediaries or mistakes by unsophisticated consumers (Agarwal et al., 2009, Campbell, 2006). We find that the provision of a risk management product with a relatively short payout history influences production behavior in the direction predicted by economic theory. The fact, however, that our results are substantially weaker for uneducated farmers may suggest that this group may either have less trust in the insurance product, or lower understanding of it.

Our results also contribute to research in corporate finance studying the effects of firm risk management on investment decisions or firm value (e.g. Campello et al. 2011; Pérez-Gonzáles and Yun, 2011; Jin and Jorion, 2006; Allayanis and Weston, 2001). One contribution we make is to study a very different setting to this previous research, focusing on small private firms in an emerging market economy. Our RCT strategy also overcomes concerns that any identified relationships between risk management practices and firm outcomes may be driven by omitted variables or other endogeneity concerns.

Two independent recent papers conduct field experiments that are closely related to ours. In India, Mobarak and Rosenzweig (2012) conduct a randomized evaluation which uses subsidies to induce households to purchase rainfall insurance: while their main interest is the interaction between insurance demand and informal risk-sharing, they also find evidence that insured households plant riskier varieties of rice. Karlan et al. (2012) randomly allocate cash grants, the opportunity to buy insurance, or both, to farmers in Ghana. They find that cash grants do not affect investment, but that the ability hedge rainfall does. Also related, Cai et al. (2012) finds evidence from China that hog insurance influences investment in hogs.

The final section of this paper studies a second, related experiment, in which we elicit farmer willingness to pay for index insurance policies, to test the market viability of index insurance. We use an incentive-compatible Becker, DeGroot and Marschak (1964, hereafter BDM) mechanism, similar in spirit to a second-price auction, in which farmers bid on and 
actually purchase insurance policies. To our knowledge, this is one of the first implementations of the BDM mechanism in a field experiment setting. We find that on average, farmers' valuation of the insurance policy exceeds our estimate of the actuarial price - this means that, if insurance were offered on terms roughly similar to retail insurance products (e.g. automobile insurance) in the United States, over half of our sample would purchase it. However, we also show that while farmers can identify changes in the contract that make the policies more or less valuable, they do less well at estimating the economic magnitude of these changes. An important implication of this result is that an insurer seeking to maximize short-term profits may be able to design a policy that appears valuable to consumers, but which does not in fact provide meaningful insurance.

The remainder of the paper is organized as follows. We first motivate our experiment by discussing the theoretical underpinning of risk-coping strategies used by households in rural areas of developing countries use. Section 2 describes the rainfall insurance product in detail, and describes our experimental design. Section 3 describes the sample and presents summary statistics. Section 4 contains our main empirical results. Section 5 contains results from the willingness to pay elicitations. Section 6 summarizes and concludes.

\section{Theoretical considerations}

The main hypothesis tested in this paper is that the provision of insurance against income risk leads households to shift towards higher-return, higher-risk production activities. Below we review existing models and evidence on this research question. In the Appendix we also present a simple model illustrating our main prediction.

\section{A. The link between insurance arrangements and production decisions}

In a setting where risk-pooling is incomplete, firms and households select among income-generating activities by considering both expected returns and the total volatility of returns. Literature on consumption insurance emphasizes the point that households can reduce consumption volatility both by ex post consumption smoothing (e.g. through borrowing and savings) and by ex ante income smoothing, that is, by selecting production 
activities that generate a less volatile income stream, generally at the cost of lower average income (Morduch, 1995; Gollier and Pratt, 1996; Walker and Ryan, 1990). Income smoothing and consumption smoothing are linked, in that better risk-coping mechanisms to insure consumption ex post will reduce the need for households to smooth income by selecting less risky activities ex ante. While consumption smoothing of income shocks has been shown to be surprisingly good in some settings (Townsend, 1994; Paxson, 1991), a substantial body of evidence suggests it is incomplete, especially for spatially covariate shocks like rainfall. See Cole et al. (2013) for further discussion and references.

Parallel theoretical research in corporate finance makes a corresponding prediction: a firm exposed to a nondiversifiable source of risk will invest less in risky production activities, in particular when the return on the risky activity is positively correlated with the existing risk exposure (Froot and Stein, 1998; Froot, Scharfstein and Stein, 1993). The key difference in this setting is that aversion to income risk is driven by financial constraints, due to moral hazard, limited commitment or other frictions, rather than directly by the concavity of the utility function. In the context we study, consisting of mainly sole proprietor landowner farmers, incentives to manage production risk are likely to be driven by both household risk aversion and financial constraints.

For farmers, income smoothing strategies include intercropping of crops with different drought tolerances, spatial separation of plots, shifting the timing and staggering of planting, moisture conservation measures such as bunds, furrows and irrigation, and diversifying household income amongst agricultural and non-agricultural sources. A number of papers find suggestive evidence of income smoothing behavior by agricultural firms in developing countries (Rosenzweig and Stark, 1989; Morduch, 1995; Dercon, 1998; Dercon and Christiaensen, 2011). ${ }^{3}$

\footnotetext{
${ }^{3}$ Rosenzweig and Stark find that farmers with more volatile profits are more likely to have a household member engaged in steady wage employment. Morduch suggests that households whose consumption is close to subsistence devote a larger share of land to safer crop varieties. Dercon finds Tanzanian farmers with a large stock of liquid assets engage in higher risk agricultural activities. Dercon and Christiaensen find that fertilizer purchases are lower among poorer Ethiopean households, in part due to their lesser ability to smooth adverse shocks ex post. This behavior appears to significantly reduce average income. Rosenzweig and Binswanger (1993) estimate that a one standard deviation increase in the variability of monsoon onset would, through reduced risk-taking, reduce
} 
The 'income smoothing' hypothesis also implies that improved access to risk management instruments will have real effects on firm values and investment in risky production activities. Empirical research for large public US corporations finds evidence in support of this prediction. In particular, Pérez-Gonzáles and Yun (2011) find using US data that the introduction of weather derivatives increases investment and values for weathersensitive electric and gas firms, while Campello et al. (2011) find that hedging affects capital investment decisions and values for a larger sample of firms, making use of a tax-based instrument. We view the research question studied in these two papers as being closely connected to the development economics literature cited above, although the empirical setting is of course very different.

We contribute in at least two ways to this prior research on the link between production decisions and risk management or insurance arrangements. One, we consider an experimental setting, in which we enforce exogenous variation in access to insurance against income risk. This eliminates concerns about omitted variable biases or other identification issues, which may be a concern in some of the studies cited above. Two, we consider a particular mechanism for smoothing ex post income and consumption, namely a rainfall index insurance product. This innovative type of micro-insurance has recently drawn significant attention in developing countries (Giné et al., 2012). Our findings shed some light on how ongoing financial innovation in the micro-insurance sector may influence decisionmaking by firms and households. ${ }^{4}$

\section{B. A simple framework}

To help fix ideas, Appendix A presents a simple model of insurance and production decisions. Using comparative statics we illustrate our main prediction: improved availability of ex post insurance against production risk will lead to greater ex ante investment in risky production activities. The intuition is that for a risk-averse farmer, greater insurance makes

agricultural profits by 15 percent for their median household, and by 35 percent for a household at the 25th percentile of income.

${ }^{4}$ Our earlier research studies the determinants of rainfall insurance demand (Cole et al. 2009, Giné and Yang, 2009, and Giné et al., 2008). While we adopt a field experimental approach, generating random variation in insurance participation, uptake has been too limited to allow an assessment of its impact on real decisions. Also related, two noteworthy laboratory experiments conducted by Lybbert et al. (2010) and Hill and Visceisza (2009) suggest that, over time, subjects learn the benefits of insurance and capitalize on it. 
risky activities more attractive, by reducing the volatility of returns on such activities. While we consider a simple CARA-normal setup that yields a closed-form solution, this basic prediction is more general, will obtain in most models with risk-averse agents, incomplete markets and production risk.

\section{Crop choice decisions and risk-taking}

The model in Appendix A considers two production activities: one safe, the other higher-yielding but risky. Empirically, our analysis examines substitution across crop types with different exposures to rainfall risk. In particular, as well as measuring total production, we collected information from farmers about their allocation of agricultural inputs to the two main cash crops grown in our study areas, castor and groundnut. These crops are more rainfall-sensitive than most traditional subsistence crops but generate higher expected yields.

During the main cropping season that runs from June to November farmers grow a variety of cash and subsistence crops that vary in terms of sensitivity to deficit rainfall. The main cash crops grown in the area are castor and groundnut, two rainfed oilseeds, as well as paddy, which is almost exclusively irrigated. ${ }^{5}$ The main subsistence crops grown in the area are sorghum and grams (red gram or Pigeon peas and to a lesser extent green gram).

Cultivation costs for the main cash crops are somewhat higher than those of subsistence crops and range between Rs 5,000 and Rs 9,000 per hectare (\$94 to \$168 US), if the recommended amounts of organic and inorganic fertilizer are applied. ${ }^{6}$ Average yields for castor are $600 \mathrm{Kg}$ per hectare if fertilizer is used amounting to Rs 10,896 using 2009 prices. ${ }^{7}$ Groundnut yields are $540 \mathrm{Kg}$ per hectare with fertilizer corresponding to Rs 11,702. Sorghum yields with fertilizer are $700 \mathrm{Kg}$ per hectare or Rs 4,788 and red gram yields are $300 \mathrm{Kg}$ or Rs 5,791. Thus, expected profits for castor and groundnut are indeed higher at Rs

\footnotetext{
${ }_{6}^{5}$ Eighty four percent of all paddy plots in our sample use irrigation.

${ }^{6}$ Input recommendations come from the University of Agricultural Sciences in Bangalore (UAS, 1999). The production costs per hectare at 2009 prices for castor include Rs 1250 for seeds, Rs 1250 for manure, Rs 3,125 for fertilizer and Rs 2500 for labor expenses including labor, land preparation, sowing, weeding and harvesting. For groundnut, Rs 3125 for seeds, Rs 625 for manure, Rs 2500 for fertilizer and Rs 2500 for labor expenses. Sorghum production costs include Rs. 450 for seeds, Rs. 550 for manure, Rs 2000 for fertilizer and Rs. 2000 for labor. For red and green grams, Rs. 650 for seeds, Rs. 750 for manure, Rs. 1500 for fertilizer and Rs. 2750 for labor expenses.

${ }^{7}$ Data on crop prices come from the district Handbook of Statistics published by the Chief Planning Officer.
} 
2,771 and Rs 2,951 compared to a negative profit of Rs 212 for sorghum and a small profit of Rs 141 for red gram. ${ }^{8}$

In terms of water requirements, researchers at the Central Research Institute for Dryland Agriculture (CRIDA) estimate that castor grown in Mahbubnagar under rainfed conditions requires $625 \mathrm{~mm}$ of accumulated rainfall over the season if sown around the normal planting date while groundnut in Anantapur requires $533 \mathrm{~mm}$. Red gram requires a similar amount of accumulated rainfall, $523 \mathrm{~mm}$ but in contrast, sorghum only requires 376 $\mathrm{mm}$ and green gram $278 \mathrm{~mm}{ }^{9}$

\section{Study design and data}

\section{A. Product description}

The rainfall insurance policies offered in this study are an example of "index insurance", that is, a contract whose payouts are linked to a publicly observable index like rainfall, temperature or a commodity price. Unlike traditional insurance products, index insurance is not generally subject to moral hazard and adverse selection problems, because payouts are linked to an exogenous, publicly observable variable, in this case, rainfall measured at a local rain gauge. Index insurance also involves lower administrative costs, because no claims verification process is required. However, rainfall insurance only covers rainfall-related losses and may entail significant basis risk, especially if the household is located too far from the relevant weather reference station. ${ }^{10}$

In part because insurance is typically bundled with credit at highly subsidized rates, index insurance markets are expanding in many emerging market economies (World Bank, 2005; Skees, 2008). Today, rainfall insurance is offered by several firms and sold in many parts of India. Giné et al. (2012), Clarke et al. (2012) and Cole et al. (2013) provide nontechnical description of this market and further institutional details.

\footnotetext{
${ }^{8}$ Although prices fluctuate year to year, expected profits will typically be larger for groundnut and castor.

${ }^{9}$ Based on personal communication from Dr. Bodapati Rao and Dr. Vijay Kumar, Principal Scientists at CRIDA.

${ }^{10}$ In our study, most villages are located within $10 \mathrm{~km}$ of the reference weather station. Given the relatively flat terrain one may think that basis risk is likely to be relatively low, at least for our sample. However, we do not have hard data on the size of this risk.
} 
The policies we study are designed and underwritten by ICICI Lombard, a large Indian insurance firm. Payoffs are calculated based on measured rainfall at a nearby government rainfall station or an automated rain gauge operated by a private third-party vendor. ICICI Lombard policies divide the monsoon season into three contiguous phases of 35-45 days, corresponding to sowing, flowering, and harvest. ${ }^{11}$ The study offered only Phase I policies, which cover the first and most critical period of the season.

Each insurance contract specifies a threshold amount of rainfall, designed to approximate the minimum required for successful crop growth. The date of the start of the policy is the first date at which cumulative total rainfall since June 1 is at least $50 \mathrm{~mm}$. Payouts are then determined based on additional cumulative rainfall during the 35 days after the start date. The policy pays out if cumulative rainfall during the coverage period is below a threshold known as the "exit". Payouts are linear in the rainfall deficit relative to the exit, or are equal to a fixed maximum amount of Rs. 1000 per policy if rainfall is below a second, lower threshold known as the "strike".

Farmers in our study received policies linked to one of five weather stations (see below for more details). Because 2009 monsoon turned out to be significantly below average, three of these five policies generated positive payouts ex post, with one of them paying out the maximum payout of Rs. 1,000 .

\section{B. The insurance experiment}

Our sample consists of 1,479 small agricultural firms drawn from 45 villages in two districts in Andhra Pradesh, Mahbubnagar and Anantapur. Many firms consist of a single family, although others hire labor. Two-thirds of the sample participated in previous research conducted by us on rainfall insurance; these were originally selected via a stratified random sample of land-owning farmers in 37 study villages in 2004 (see Giné et al., 2008, for details). In 2009, to improve statistical power for this study, an additional 500 households were drawn from these 37 villages as well as 8 nearby villages.

\footnotetext{
${ }^{11}$ Since monsoon onset varies across years, the start of the first phase is defined as the day in June when accumulated rainfall since June 1 exceeds $50 \mathrm{~mm}$. If $<50 \mathrm{~mm}$ of rain falls in June, the first phase begins automatically on July 1.
} 
Each farming household received a visit to their home in June 2009, at the onset of the 2009 monsoon season, from a member of a trained team of enumerators from the agricultural research organization ICRISAT. During the visit, the enumerator first conducted a short survey, collecting demographic information and data on practices by the farmer during the previous monsoon. They then explained the recommended fertilizer dosages for castor and groundnut, the two main rain-fed cash crops in the area. The enumerator then explained the concept of insurance to the household, and gave specific details about the policies offered by ICICI Lombard.

Each farmer was then given a scratch card (similar to the format of a scratch-off lottery ticket in the United States), revealing one of two treatments. The key treatment for the purposes of this paper is the assignment of the household to either an insurance group or a control group. The insurance treatment group received 10 Phase-I weather insurance policies, similar to those sold in the region in previous years (as described in Section 2.A). The "control" group was promised a fixed future cash payment of Rs. 350 (i.e. our estimate of the expected payouts of these 10 policies). This compensation was offered to ensure that differences in behavior between the insurance and control group would be due to the statecontingent nature of the insurance, rather than any wealth effects arising from the expected value of the insurance. The fixed payment was also promised to be delivered at the same time as the insurance payouts, so that differences in behavior would not be driven by differences in the timing of payments.

A second independent treatment was also provided via the scratch card, involving coupons for discounts on locally appropriate inorganic fertilizer (DAP in Anantapur, NP fertilizer in Mahbubnagar). Unfortunately the implementation of this treatment was largely unsuccessful because of logistical issues in the field ${ }^{12}$; for that reason, we do not study it here.

\footnotetext{
${ }^{12}$ The number of coupons (or bags) with a subsidy was calibrated to fertilizer usage reported in a survey conducted in 2006. According to that survey, 70 percent of farmers in Mahbubnagar but only 34.4 percent in Anantapur had used fertilizer and those that did would purchase at most two bags. However, follow-up data collected in November 2009 revealed much higher fertilizer usage (see Section 4.F for details).
} 
Treatments were applied randomly and independently across households. The use of scratch cards ensured that neither the respondent nor the enumerator was aware of the household's treatment status while the survey was being conducted. Farmers also had the option to purchase additional insurance policies independently from the local vendor, BASIX, although few did so in practice.

In November 2009, after the growing season, the ICRISAT team revisited each study household, and conducted a follow-up survey. In addition to demographic data, the survey collected information on livestock, financial assets (including savings, loans, and insurance), agricultural investments and production decisions during the monsoon, as well as attitudes towards and expectations of weather and insurance payout, and risk-coping behavior.

Although no payouts had been made by the time the follow-up survey concluded, because of the poor monsoon in $2009,93 \%$ of the farmers in the treated group expected to receive a payout. In addition, roughly the same percentage thought that crop yields would be below average.

Figure 1 plots realized cumulative total rainfall (blue line) and cumulative "index" rainfall (measured from when the policy started), for each of the five policies. The gold horizontal lines represent the strike (top) and exit (bottom) levels of rainfall for each rainfall station in the study. For example, in Naryanpet, rainfall was very low in June, never reaching the trigger amount of $50 \mathrm{~mm}$. Thus, the policy started automatically on July $1^{\text {st }}$. Rainfall levels quickly cross the exit $(5 \mathrm{~mm})$ level, but never exceeded $16 \mathrm{~mm}$. Each policy therefore triggered a payout of Rs. 10 x (50-16), or Rs. 340. Since each treated farmer received ten policies, each farmer received a total payout of Rs. 3,400. Farmers in Anantapur received per-policy payouts of (30-10) x $10=$ Rs. 200 (i.e. Rs. 2,000 in total). In Hindupur, no rainfall fell in the month of July, triggering the 'exit'; consequently, farmers received a payout of Rs. 1,000 per policy, or Rs. 10,000 in total. This amount is significant: it is equivalent to $90 \%$ of median savings for our sample, measured as of the start of the monsoon.

[Insert figure 1 here] 
Payouts to the insurance and control group were made in December 2010 and January 2011. Notably, this timing was well after one might have expected, given that the policies indicate a settlement date of "thirty days after the data release by data provider and verified by Insurer." However, the timing was relatively consistent with previous monsoon seasons. The long timeframe for payment of insurance payouts reflected both slow release of the data by the relevant collectors and slow processing by ICICI Lombard.

\section{Summary Statistics}

Table 1 presents summary statistics for baseline characteristics the sample, based on the baseline and follow up surveys conducted before and after the 2009 monsoon season. Logistical constraints precluded conducting an extremely detailed baseline survey, however detailed historical planting and demographic data are available for the households that were included in earlier studies. For the households added to the sample in 2009, we asked respondents in November 2009 to provide information about fixed characteristics (e.g., schooling) and provide recall data on the value of livestock and other assets as of June 2009.

[Insert table 1 here]

Panel A presents basic demographic data. The average household has 5.35 members with a 49.6-year old household head; most household heads (91\%) are male. On average, household heads have obtained 3.75 years of schooling, with over half (54\%) reporting being "unschooled." Literacy is low, with respectively only 44 and 41 percent of heads reporting being able to read and write. These basic household characteristics are similar to the general sample of farmers studied in our previous work (e.g. see the summary statistics presented in Cole et al. 2013, which are based on a 2006 survey instrument). Given that assignment to the insurance treatment and control group was randomized, we would not expect to observe statistically significant systematic differences between the characteristics of households offered insurance (treatment) and those offered cash equivalent (control). This hypothesis is tested in Appendix Table A1, for demographic characteristics (Panel A), livestock and other assets including land (Panel B), financial assets and credit (Panel C), (Panel D), as well as 
agricultural investments during the 2008 monsoon. Validating the randomization, we find a statistically significant difference between the two groups only for one variable, the use of non-traditional savings variables.

In Table 2, we report agricultural investment decisions for the year of our intervention, the summer of 2009. An overwhelming majority (93\%) of farmers planted some crop in 2009 , and roughly $48 \%$ of farmers planted cash crops. We note that the fraction of farmers planting cash crops is significantly higher in 2008 than in 2009. This reflects the poor realized quality of the 2009 monsoon.

[Insert table 2 here]

\section{Estimation results}

\section{A. Baseline estimates}

Table 3 presents estimates of the local average treatment effect of the insurance treatment on farmers' agricultural investments during the 2009 monsoon. As discussed in section 3, we measure investments in agricultural inputs (i.e. the market value of the input actually used by the farmer) across a number of categories, including seeds, fertilizer, manure, pesticide, irrigation and hired labor. These are measured in the follow-up survey conducted after the end of the monsoon. They reflect total investments for all crops, including castor and groundnut but also lower-yielding crops such as sorghum. For five investment categories, we separately also measure the value of the input used only for the production of the cash crops castor and groundnut. We also record information about the area of land sown under castor, groundnut and in total, amongst other follow-up information.

Table 3 studies four outcome variables: (i) a dummy equal to one if any agricultural inputs were used during the monsoon, (ii) the area of land sown, (iii) the market value of agricultural inputs used, and (iv) the value of agricultural inputs purchased. For the first three outcome variables, we separately study inputs used for the production of castor and groundnut. (We did not collect this information for the "market value of inputs purchased" variable). These cash crop estimates are presented separately in the table. 
[Insert table 3 here]

In Section A each outcome variable is regressed on a dummy for whether the household received the insurance treatment (the key variable of interest), a set of village dummies, and a dummy for an independent fertilizer treatment. A tobit estimator is used for the continuous variables, and a probit for the "any inputs used" dummy. To conserve space, only results for the coefficient of interest are presented. Specifications in section B are otherwise identical, except that they include measures of household socioeconomic status as additional controls. This is done as a robustness check. Adding the controls has little effect on our estimates, unsurprisingly, given that farmers were assigned randomly to the treatment and control groups (i.e. assignment should be uncorrelated with these household controls).

Studying investments in all crop types (the first column of results), we find a consistently positive although statistically insignificant effect of the insurance treatment on farmers' input decisions. If the analysis is restricted to castor and groundnut investments, however, the treatment effects are quantitatively much larger, and consistently statistically significant (at the $5 \%$ level or better) in each specification. Quantitatively, the probability of planting cash crops increases by 6 percentage points (or 12 percent). Ln(1+land planted for cash crops) increases by 0.163 , equivalent to a 27 percent increase in land sown for a farmer who would have planted 2 acres of cash crops in the absence of the treatment. ${ }^{13}$

As a different way of viewing this relationship, figure 2 plots the cumulative density function of investment in cash crops by insurance treatment status. Underlying the average treatment effects presented in table 3, it appears that the effect of the insurance treatment is quite non-linear. A sizeable number of farmers are pushed from not growing cash crops into growing cash crops, as also shown in the regression results. But for those farmers in the top part of the distribution of cash crop investments, insurance provision has little or no effect on investment in castor and groundnut. In other words, the effect of insurance is primarily on the extensive rather than the intensive margin.

\footnotetext{
${ }^{13}$ If the farmer originally planted to sow two acres of cash crops, our point estimate implies that the new quantity of land planted for cash crops will be $\exp ((\ln (1+2)+0.163)-1)=2.53$ acres, a $26.5 \%$ increase. Recall that about half the farmers in our sample plant no cash crops during the 2009 monsoon. A small minority planted no crops at all. This is due to the poor realized quality of the 2009 monsoon.
} 
[Insert figure 2 here]

We also note from figure 2 that there is a discrete jump in cash crop investment once the farmer decides to invest a positive amount. This points to the presence of scale economies; it is inefficient for farmers to sow cash crops below a minimum scale. Around this threshold, access to insurance against income risk makes farmers more willing to invest a positive amount in castor and/or groundnut.

\section{B. Individual inputs}

Table 4 decomposes the average treatment effect estimates for cash crops by individual input type. These individual inputs are measured with less statistical power than their sum. The treatment effect for each input is positive in all ten cases, however it is generally not statistically significant, except in the case of pesticide.

[Insert table 4 here]

\section{Interaction effects}

In Table 5, we test for heterogeneity in the treatment effect identified above, by measures of household wealth, education and expectations. We estimate regressions of the form:

outcome $=f(a+b$. insurance $+\mathrm{c}$. characteristic $+d$. insurance $\mathrm{x}$ characteristic $+\ldots+\mathrm{e})$.

where "insurance" is a dummy for insurance treatment status, and "characteristic" is the source of heterogeneity of interest (e.g. wealth, education etc.). The primary coefficient of interest is the coefficient $d$ on the interaction term in this regression. As in table 4, we consider three outcome variables, a dummy for whether the farmer plants cash crops, the value of their investment in cash crops, and the area of land planted with cash crops.

[Insert table 5 here]

We first study how the insurance treatment effect varies with two wealth measures: acres of land owned, and a wealth index derived as the first principal component of asset holdings (as described in table 3). These are included as interaction characteristics one at a time. It is unclear what effect is expected. On one hand, wealthier households may have 
better ex post consumption insurance against adverse shocks (as in Mobarak and Rosenzweig, 2012), making them less likely to respond to rainfall insurance. On the other hand, wealthy farmers may be in a better position to adjust agricultural practices in response to a shift in the risk-return frontier introduced by insurance (e.g. because they are less financially constrained). Empirically we find mixed and weak results - the treatment effect is increasing in landholdings but decreasing in the wealth index; neither is statistically significant. We note that the uninteracted coefficient on both these terms is however highly positive and statistically significant, as expected (i.e., wealthy farmers are much more likely to invest in cash crops).

Next, we consider heterogeneity by two measures of educational attainment: log years of education, and a dummy for whether the household head is literate. Strikingly, we find large, positive and highly statistically significant interaction effects between the insurance treatment and both of these education measures. In other words, the treatment effect of insurance provision on production behavior is concentrated amongst educated households. This heterogeneity by educational attainment is economically as well as statistically significant. Among literate farmers, assignment to the insurance treatment group increases the likelihood of investing in cash crops by 15 percentage points; among illiterate farmers, the treatment effect is indistinguishable from zero.

In the last part of the table, we consider an index that specifically measures the farmer's knowledge of the insurance product (measured ex ante). The interaction term for this variable is positive although not statistically significant. In other words, it is the farmer's overall education level, not their specific measured knowledge of the insurance policy, that appears to matter for the strength of the treatment effect. We also find no evidence of significant heterogeneity in the strength of the treatment affect associated with the farmer's measured expectations about the dispersion of yields. ${ }^{14}$

\footnotetext{
${ }^{14}$ In unreported regression specifications (available on request), we also test whether those more likely to have purchased insurance in the past behave differently. We focus on exogenous likelihood of having purchased insurance, using randomly assigned marketing treatments from prior years (described in Cole et al., 2013) to predict a probability of purchase. It may be the case that those more experience with the insurance product trust the product, and are hence more likely to change behavior. We do not find any differential effect among those who were more likely to have purchased insurance.
} 
Summing up, we find strikingly significant evidence that the insurance treatment effects are concentrated amongst educated farmers, although little evidence of significant heterogeneity in other dimensions, at least given the power of our statistical tests. Our finding on education has interesting implications for the distributional effects of financial innovation. We note a caveat on our conclusions, however - while our insurance treatment is randomly assigned, these household characteristics of course are not. Thus, it is possible that our results could reflect omitted variables which are correlated with educational attainment, but not with wealth.

\section{Timing}

Figure 3 presents estimates of how the insurance treatment affects the timing of investments in cash crops. This figure is constructed by estimating a series of regressions similar to those from table 4 that trace out how the insurance treatment affects the probability of planting cash crops by different points in the monsoon season. Indicated on the figure is the start and end of the period in which the insurance treatment was given to households.

\section{[Insert figure 3 here]}

The insurance treatment effect is extremely close to zero at the point the insurance policies are randomly allocated across farmers. The cumulative treatment effect by date then rises sharply, becoming statistically significant prior to the average end of the realized insurance coverage period (this end point varies by policy). It then flattens out, and ultimately converges to the point estimate from the average treatment effect regression presented in table 3.

This figure illustrates the fact that the effect of the insurance on behavior appears to be ex ante in nature; it occurs well before the end of the insurance coverage period, and many months before the insurance payout itself is received. This is consistent with the interpretation that farmers view insurance as being a reason to take riskier ex ante production decisions, in the knowledge that they are partially hedged in the event of a poor monsoon outcome, consistent with the theoretical model presented in the Appendix, and the literature cited earlier. 
As a further test of this "ex ante" interpretation of our findings, we re-estimate the interaction specification from table 5 using ex post realized payouts as the interaction variable. This interaction variable is quantitatively small and statistically insignificant. This suggests farmers' monsoon investment responses to the insurance treatment are not simply a response to an anticipation of receiving high payouts due to low expected rainfall.

\section{E. Qualitative self-reported changes in behavior}

To complement the quantitative evidence presented above, in the follow-up survey conducted after the monsoon, we also simply asked farmers from the insure sample whether and how the provision of insurance affected their investment behavior. For example, we ask farmers whether the knowledge that they held rainfall insurance led to an increase, decrease or no change in the amount of fertilizer, seeds and other inputs they used, and whether it influenced decisions about planting, replanting and/or abandoning crops. Results are presented in table 6 .

[Insert table 6 here]

We find that a significant fraction of respondents report not changing their behavior, but that amongst those that did, most reported increasing investments in agricultural inputs, rather than reducing them. For example, 50\% reported using more fertilizer, while only $14 \%$ reported using less fertilizer. More generally, a larger fraction of respondents indicated that they used more seeds, more pesticide, more hired labor, and borrowed more, in comparison with those who reported "used less", though some of these differences are quite modest. The only input of which farmers said they were influenced to use less on average was bullock labor. Farmers also report that their awareness of being insured also influenced them towards planting earlier, and against abandoning crops.

We view this evidence as being suggestive at best, given the qualitative nature of the questions posed to farmers. We did not ask farmers to estimate the size of their investment responses, for example. However, to the extent that weight should be placed on these responses, they appear consistent with our overall finding of a relationship between insurance and investment in risky agricultural activities. 


\section{F. Other robustness checks}

We have conducted a number of additional unreported robustness checks on the results presented above, that are omitted from the tables because of space considerations. Concerned about the potential influence of outlier observations for the continuous variables we use, we re-estimated our main results after winsorizing the top and bottom $2 \%$ of all continuous variables. This has little effect on our results. Estimating linear probability models instead of using tobit and probit estimators also has fairly modest effects on the results, as does adding further household characteristics as controls.

\section{5: Willingness to pay for insurance}

The evidence presented above suggests that that increased ownership of the risk management instrument leads farmers to select a portfolio of crops with higher expected returns. In this section, we report on an experiment, conducted one year later, which measures farmer willingness to pay for rainfall insurance with varying contract terms, using the incentive-compatible BDM mechanism. Willingness to pay is elicited for four different policies, varying the contract terms to understand what features farmers value most.

The goal of this follow-up experiment is to understand how consumers value these complex insurance products and to provide insight into their long-run commercial viability.

\section{A. Experimental design}

The experiment was conducted with a sample of 1,978 farmers comprising 1,464 participants from the 2009 study described above, as well as 514 new subjects randomly selected from the same and nearby villages. An interviewer visited each household between May and August 2010 and offered individuals the chance to participate in a game in which they would have the opportunity to purchase rainfall insurance policies at a discounted price. If the respondent agreed, the interviewer explained the BDM mechanism and the experimental procedure as follows.

The subject would have a chance to study the details of an insurance policy, and then record, in rupees, her willingness to pay for it. She would examine, and record a price, for 
four different policies. However, only one of these four policies would in fact be available for sale. The policy for sale would be revealed only after the subject had stated willingness to pay for all four policies. This would be done by scratching off the opaque surface on a scratch card.

The scratch card would also indicate the offer price for the insurance policy selected. If the subject's bid were greater than or equal to the offer price, the subject would purchase the policy, at the price on the scratch card. If the subject's bid were less than the offer price, no insurance policy would be sold.

Since this was a slightly complicated mechanism, great care was taken to explain the mechanism to participants. Individuals had the opportunity to familiarize themselves with the structure of the game by simulating the initial round of the game bidding for a chocolate bar.

\section{B. Insurance Policies}

The policies resembled typical rainfall insurance policies sold in the area. Each policy covered approximately one-eighth of the production costs of the main cash crop in the area in one acre of land, with a coverage period of 35 days. The period of the monsoon that was covered was split into two phases: Phase I polices provided coverage for the sowing period, while Phase II covering the podding period. Initially, farmers were offered Phase I policies. But 1,432 households were visited after the cut-off date to sell Phase I policies had passed; these households were offered Phase II policies instead. ${ }^{15}$

In each village, the nearest rainfall station was identified. As in our 2009 experiments, the experiment used policies relating to five rainfall stations: Atmakur, Mahbubnagar, Narayanpet in the Mahbubnagar district and Anantapur and Hindupur in the Anantapur district.

Each household participating in the game bid for four different policies, which were chosen by us to test different theories of insurance demand. In particular, the complexity of the rainfall insurance product may raise concerns about individuals' ability to evaluate it. The

15 The coverage period of Phase I policies was activated once the total cumulative rainfall in the month of June had exceeded $50 \mathrm{~mm}$, which occurred on June 12. 
four policies individuals were asked to bid are described below. ${ }^{16}$ Their exact contract features are given in table 7. In addition, we compute the expected value of actual and modified policies, based on historical rainfall data, for the two districts for which data are available (Anantapur and Mahbubnagar).

- Real Policy - This was the actual policy, designed by the insurance company ICICI Lombard, and targeted at farmers in the area.

- Modified Exit - The insurance contracts paid a large sum (Rs. 1,000) if an "exit" condition was reached, which was meant to correspond to total crop failure. In the real policies, this exit level was often 0 , but sometimes 5 , 6 , or $10 \mathrm{~mm}$. In the modified exit policies, the bar for the maximum payout was raised by $5 \mathrm{~mm}$. For example, the Real Policy for Anantapur Phase II had an exit of $0 \mathrm{~mm}$, while the Modified Exit had an exit of $5 \mathrm{~mm}$. This shift has a dramatic effect on value, increasing the expected payout of the policy by 40 and 65 Rupees in Anantapuram and Mahbubnagar, respectively.

- Modified mm payment - Recall that policies are designed such that any rainfall below the strike level results in payouts. If the rainfall falls between the strike and the exit, the Real Policy pays Rs. 10 per mm of deficit. For example, for Anantapur Phase II, the strike is $30 \mathrm{~mm}$. The Real Policy would pay Rs. 100 if actual rainfall were Rs. $20 \mathrm{~mm}$ (10 Rs. for each $\mathrm{mm}$ deficit). The modified $\mathrm{mm}$ payment policy reduced the amount paid per $\mathrm{mm}$ to Rs. 5. Hence, an actual rainfall of $20 \mathrm{~mm}$ would result in a payout of only Rs. 50 in the modified mm payment. Because much of the expected value of the policy is driven by tail events, this has a much more modest effect on the expected value of the policy, reducing it by 22 and 11 rupees in Anantapur and Mahbubnagar, respectively.

- Basis Risk - To understand how important basis risk is to clients, the "Basis Risk" policy was randomly assigned to be a real policy, but one based on a distant rainfall station. This manipulation changes the correlation of payouts with the farmers' likely

16 In addition, farmers bid on a package of ten real policies. We omit results on that bidding from this paper. 
loss, but because the policies were calibrated by the insurance company to have roughly the same expected value, does not change the mean payout appreciably.

[Insert table 7 here]

Expected values were calculated using historical rainfall data. Unfortunately, data issues limit the set of policies for which we can currently calculate expected values.

The use of scratch cards made clear to the participant that the policy and offer price were pre-determined, and that her answers would not affect which policy was actually sold, or the price at which it was offered. The policy offered to each household was always the actual ICICI Lombard policy sold in the area. The offer price was randomly drawn from a uniform distribution between 0 and the face value of the policy.

To examine the possibility of anchoring effects, that is, that the order in which participants were offered policies might affect the bidding price, each individual was shown policies in one of two randomly selected order: Ordering 1 (Real Policy, Modified Exit, Modified mm payment, and Basis Risk), and Ordering 2 (Basis Risk, Modified mm payment, Modified Exit, and Real Policy). As discussed above, the three policies presented that were not the true policies differed in one and only one contract feature, but were otherwise identical along all other dimensions.

While in principal participants might have "reneged" on their offer price, and failed to complete a transaction, in practice we did not record any instance of participants declining to purchase a policy at a price below their stated willingness to pay. Participants were not told that any particular policy was real or not real, nor were they told how the policy offered to them was selected by the research team.

\section{Results}

We first verify that there were no anchoring effects in reported bids. Table 8 reports average bid for each of the four policies we consider. The column marked "Ordering 1 Mean" lists the average bids received for the policies in the standard ordering (Real, Exit, $\mathrm{mm}$ deviation, basis risk), while the next column lists the average bids for the reversed ordering. As is apparent from the similarity between the numbers listed in the two columns, 
the order in which the policies were presented did not significantly affect farmers' willingness to pay. The remaining columns of Table 8 provide the mean, standard deviation, and percentile distribution of bids for various policies.

[Insert table 8 here]

The average bid for the "real" policy is Rs. 68.4, which is less than the face value charged for the policy (Rs. 100-110, depending on the policy), but greater than our estimate of the expected payout (Rs. 44-54). Indeed, the median bid is 70, well above the actuarial price of the policy. ${ }^{17}$ This suggests that, if distribution costs were reduced dramatically-for example, by allowing purchase, and claims payouts - with mobile money, or by lowering the loading factors especially for policies linked to rainfall stations with a long series of historical data, the policies could be quite successful commercially. ${ }^{18}$

Table 9 reports the main results of this experiment: regressions of farmer willingness to pay on contract type. Results for Phase I bids are in column (1), Phase II bids in column (2), and all bids pooled in Column (3). The results are consistent across specification. Relative to the real policy, farmers' valuation falls by 12-13 rupees when the policy offers a smaller payout of only Rs. 5 per mm shortfall. In contrast, increasing the rainfall threshold for the "exit" (large payment) to occur, increases willingness to pay by approximately the same amount, Rs. 11.

[Insert table 9 here]

This finding is striking and has implications for the pricing of such polices. On average, the farmers clearly understand that the tweaks (lower mm deviation payment; higher threshold for exit) affect the value of the policy, and adjust their valuations in the directions predicted by a rational expectations benchmark. However, they do not get the magnitudes right, even from an expected value perspective: the former reduces the expected value of policies by Rs. 10-20, while the latter increases the expected value by Rs. 40-70.

\footnotetext{
${ }^{17}$ In fact, these bids may be an underestimate of actual willingness to pay, as farmers never bid more than the face value of the policy.

${ }^{18}$ In the U.S., the ratio of claims to premiums is 76.2 percent for automobile insurance, and 64.7 percent for homeowner's insurance. Rainfall insurance policies sold for Rs. 70 (the median bid), with an average payout of Rs. 50 would fall within that range, and in fact involve much less administrative cost, since there would be neither risk assessment nor claims verification.
} 
The fact that farmers are likely to be risk averse makes these differential responses even more puzzling. The "exit" policy increases the probability the policy will pay out large amounts, in times of severe drought (yields are likely to be very low whether rainfall is 0 or 5 $\mathrm{mm}$ ). In contrast the "mm" policy affects the size of payment when droughts are less severe. Put differently, farmers seem less sensitive to changes to the policy terms that affect payouts in low-probability events and relatively more sensitive to changes in the policy terms that affect more often payouts. As a result, there may be a disconnect between what farmers want, i.e. policies with higher frequency payouts and what farmers may need given risk aversion, i.e. policies that pay relatively more in low-probability events.

Finally, the coefficient on the indicator for the policy that induces substantial basis risk is negative and very large, roughly halving farmers' willingness to pay for policies. Choosing a distant rainfall station did not affect the average payout of the policy. This suggests that farmers are quite sensitive to basis risk, and that efforts to improve index policies to reduce basis risk, such as using satellite imagery or a denser network of weather stations may substantially improve the value of products to customers.

Column (4) adds controls for new participants, who express a higher average willingness to pay than individuals part of the original sample, for policy ordering, which is not significant, and for income distribution quartiles. Richer households express a higher willingness to pay, though the spread is not particularly large (6 Rs. per policy).

In Table 10, we ask whether all farmers react in the same way to changes in contract features, or whether there is heterogeneity in response. Specifically, we split the sample into quartiles based on income (column 1), education (column 2), and self-assessed financial sophistication. Each regression includes the same policy dummies as before, as well as quartile dummies for income, education, or sophistication, and finally interaction terms between this quartile value (equal to 1,2,3, or 4) and a dummy for the alternative policies.

[Insert table 10 here]

The results in column 1 suggest that wealthier individuals are willing to pay more for insurance. Examining heterogeneous effects, the only interaction that is significant is with 
exit, though the magnitude is not meaningful: the poorest quartile would pay Rs. 11.3 more for a policy with a higher exit threshold, while the richest quartile would pay only 10.3 for the policy. Similarly, we do not observe systematic variation by education quartile. ${ }^{19}$

The most interesting pattern emerges in column (3). Here, we find that financially sophisticated households are more sensitive to changes in contract terms, and that these changes go in the "right" direction. Moving from the least to most sophisticated quartile, for example, roughly doubles the reduction in willingness to pay for the $\mathrm{mm}$ Dev policy, and increases by $50 \%$ the willingness to pay for the modified exit policy.

\section{Discussion}

Taken together, these results have several important implications for the development of the weather insurance market. They imply that rainfall insurance in India, marketed with loading (expected payout) at the same level as standard policies in the United States, would face robust demand: over half of farmers whose willingness to pay we elicit would purchase in at this price. Moreover, there may be considerable scope for improving the policy, as experimentally induced basis risk resulted in dramatically lower valuation.

However, the results also suggest that relying exclusively on an unregulated private sector may not lead to contracts that maximize consumer welfare. Limited financial sophistication may present an important barrier. Consumer willingness to pay varies with features of the product, but customers appear to misprice certain contract terms relative to others. An insurance company seeking to maximize short-term profit may design a policy with features consumers find valuable, but which offers relatively little value to the consumer. While one might hope that agents could help customers select the best policy, the record of insurance agents in India in this regard is not encouraging (Anagol, Cole and Sarkar, 2013).

Finally, from a methodological perspective, the experiment demonstrates the utility of the BDM in the field, and shows how a simple experimental set-up, involving the cost of a

\footnotetext{
${ }^{19}$ Roughly $51 \%$ of household heads report the lowest level of schooling: these individuals are assigned to the first quartile; the remaining half is assigned to either the third or fourth quartile.
} 
single household visit, can immediately yield credible data that can be used to answer a number of questions. ${ }^{20}$

\section{Further discussion and conclusions}

We find evidence that the provision of insurance against an important source of production risk influences production decisions by our sample of small agricultural firms. This change in behavior occurs primarily through a substitution in agricultural investments towards higher-risk, higher-return cash crops, and is concentrated amongst educated farmers. Our results, alongside complementary independent recent work by Mobarak and Rosensweig (2012), Karlan et al. (2012) and Cai et al. (2012), suggests that insurance arrangements that "fill in" missing markets have significant effects on production and risk-taking.

The lack a discernible effect of insurance coverage on total agricultural expenditures and land use could be consistent with the presence of fixed short-run production factors (e.g. a given amount of land, which cannot be easily adjusted in the short run), or the presence of financial constraints. It could also reflect limited statistical power of our tests.

We emphasize the point that our results measure the ex ante effects of insurance on behavior. Insurance may have further effects on behavior after payouts are received by farmers. While the period over which we measure behavior ends significantly before payouts were received, it is possible that our findings in part reflect anticipation of future payouts by farmers. We note however that the strength of the treatment effects we estimate is uncorrelated with actual realized payouts, suggesting that this anticipation channel is not the primary mechanism driving our results.

We emphasize that our evidence does not provide a direct estimate of the welfare benefits of access to insurance. Indeed, previous research discusses the fact that take-up of rainfall index insurance has been modest to date. Cole et al. (2013) discuss the determinants of insurance demand in detail, highlighting that high prices relative to expected payoffs are one reason for low demand. The BDM experiments described in this paper confirm that

\footnotetext{
${ }^{20} \mathrm{We}$ are aware of two other implementations of the BDM mechanism in the field: Cole, Stein and Tobacman (2011), and Berry et al. (2012).
} 
insurance demand is significantly price sensitive. Rainfall index insurance coverage is increasing over time; Cole, Stein, and Tobacman (2010) find increasing levels of take-up in Gujarat, and in regions of India, commercial sales have been quite high. Still, we are aware of no data set in which farmers have close to as much coverage as those in this study.

Through the lens of corporate finance, our findings are consistent with theoretical models predicting an interaction between risk management and production or investment decisions (e.g. Froot and Stein, 1998). From a development economics perspective, they suggest that incomplete insurance may be an important constraint on development. Consequently, financial innovations that improve risk diversification, such as the insurance policy studied here, may play a significant role in boosting growth and real incomes in emerging market economies.

\section{References}

Agarwal, Sumit, John Driscoll, Xavier Gabaix and David Laibson, The Age of Reason: Financial Decisions over the Lifecycle with Implications for Regulation, Brookings Papers on Economic Activity, 2009, Vol. Fall, Pp. 51-117

Allayanis, Giorgio and James Weston, 2001, The Use of Foreign Currency Derivatives and Firm Market Value, Review of Financial Studies, 14(1), 243-276.

Anagol, Santosh, Shawn Cole, and Shayak Sarkar, 2013 "Understanding the Advice of Commissions-Motivated Agents: Evidence from the Indian Life Insurance Market." Harvard Business School Working Paper 12-055.

Becker, G., DeGroot, M. and Marschak, J., 1964, Measuring utility by a single-response sequential method. Behavioural Science, 9 (July), pp. 226-32.

Berry, James, Greg Fischer, and Raymond Guiteras. 2012, Incentive Compatibility in the Field: A Test of the Becker-DeGroot-Marschak Mechanism. Working Paper, Cornell University.

Bodie, Zvi \& Merton, Robert C. \& Samuelson, William F., 1992. Labor supply flexibility and portfolio choice in a life cycle model, Journal of Economic Dynamics and Control, Elsevier, vol. 16(3-4), pages 427-449. 
Cai, Hongbin, Yuyu Chen, Hanming Fang and Li-An Zhou, 2012, The Effect of Microinsurance on Economic Activities: Evidence from a Randomized Natural Field Experiment, Working Paper, University of Pennsylvania.

Campbell, John, 2006, Household Finance, Journal of Finance, 61(4), 1553-1604.

Campello, Murillo, Chen Lin, Yue Ma and Hong Zou, 2011, The Real and Financial Implications of Corporate Hedging, Journal of Finance 66, 5, 1615-1647.

Clarke, Daniel, Olivier Mahul, Kolli Rao and Niraj Verma. 2012. "Weather Based Crop Insurance in India" World Bank Policy Research Working Paper 5985.

Cole, Shawn, Xavier Giné, Jeremy Tobacman, Petia Topalova, Robert Townsend and James Vickery, 2013, Barriers to Household Risk Management: Evidence From India. American Economic Journal: Applied Economics, 5(1), 104-35.

Cole, Shawn, Daniel Stein and Jeremy Tobacman, 2011, What Is Rainfall Index Insurance Worth? A Comparison of Valuation Techniques, Working Paper, London School of Economics.

Dercon, Stefan, 1998. Wealth, risk and activity choice: cattle in Western Tanzania, Journal of Development Economics, Elsevier, vol. 55(1), pages 1-42, February.

Dercon, Stefan and Luc Christiaensen, 2011. Consumption risk, technology adoption and poverty traps: Evidence from Ethiopia, Journal of Development Economics, Elsevier, vol. 96(2), pages 159-173, November.

Duflo, Esther, Michael Kremer and Jonathan Robinson, 2008, How High are Rates of Return to Fertilizer? Evidence from Field Experiments in Kenya, American Economic Review Papers and Proceedings 98 (2): 482-388.

Froot, Kenneth, David Scharfstein and Jeremy Stein, 1993, Risk Management: Coordinating Corporate Investment and Financing Policies, Journal of Finance, 48, 1629-1658.

Froot, Kenneth A., and Jeremy C. Stein, 1998, Risk Management, Capital Budgeting and Capital Structure Policy for Financial Institutions: An Integrated Approach, Journal of Financial Economics, 47, 55-82.

Giné, Xavier, Lev Menand, Robert Townsend and James Vickery. 2012. "Microinsurance: A Case Study of the Indian Rainfall Index Insurance Market" in Ghate, Chetan (ed.), Handbook of the Indian Economy, Oxford University Press.

Giné, Xavier, Robert Townsend and James Vickery, 2008, Patterns of Rainfall Insurance Participation in Rural India, World Bank Economic Review, 22, 539-566. 
Gollier, Christian \& Pratt, John W, 1996. "Risk Vulnerability and the Tempering Effect of Background Risk,"Econometrica, Econometric Society, vol. 64(5), pages 1109-23, September.

Goswami, B. N., V. Venugopal, D. Sengupta, M.S. Madhusoodanan, and Prince K. Xavier, 2003, Increasing Trend of Extreme Rain Events Over India in a Warming Environment. 314(5804):1442-1445.

Guiteras, Ray, 2009. "The Impact of Climate Change on Indian Agriculture," working paper, University of Maryland.

Hill, Ruth Vargas and Angelino Viceisza, 2009, An Experiment on the Impact of Weather Shocks and Insurance on Risky Investment. Mimeo, IFPRI.

Jayachandran, Seema, 2006, Selling Labor Low: Wage Responses to Productivity Shocks in Developing Countries, Journal of Political Economy, 114, 538-575.

Jin, Yanbo, and Philippe Jorion, 2006, Firm value and hedging: Evidence from U.S. oil and gas producers, Journal of Finance 66, 893-919.

Karlan, Dean, Robert Osei, Isaac Osei-Akoto and Chris Udry, 2012, Agricultural Decisions after Relaxing Credit and Risk Constraints, working paper, Yale University.

Lybbert, Travis J., Francisco B. Galarza, John McPeak, Christopher B. Barrett, Stephen R. Boucher, Michael R. Carter, Sommarat Chantarat, Aziz Fadlaoui, and Andrew Mude, 2010, Dynamic Field Experiments in Development Economics: Risk Valuation in Morocco, Kenya, and Peru, Agricultural and Resource Economics Review 39/2 (April 2010), 1-17.

Maccini, Sharon and Dean Yang, 2009, Under the Weather: Health, Schooling and Economic Consequences of Early-Life Rainfall, American Economic Review, 99(3), 1006-1026.

Mobarak, Ahmed Mushfiq, and Mark Rosenzweig, 2012, Selling Formal Insurance to Informally Insured, working paper, Yale University.

Morduch, Jonathan, 1995, Income Smoothing and Consumption Smoothing, Journal of Economic Perspectives, 9, 103-114.

Paxson, Christina, 1992, Using Weather Variability to Estimate the Response of Savings to Transitory Income in Thailand, American Economic Review, 82(1), 15-33.

Pérez-Gonzáles, Francisco and Hayong Yun, 2011, Risk Management and Firm Value: Evidence from Weather Derivatives, Journal of Finance, forthcoming.

Rose, Eliana, 1999, Consumption Smoothing and Excess Female Mortality in Rural India, Review of Economics and Statistics, 81(1):41-49. 
Rosenzweig, Mark R. and Hans P. Binswanger, 1993, Wealth, Weather Risk and the Profitability of Agricultural Investment, Economic Journal, 103, 56-78.

Rosenzweig, Mark R \& Stark, Oded, 1989. "Consumption Smoothing, Migration, and Marriage: Evidence from Rural India,"Journal of Political Economy, University of Chicago Press, vol. 97(4), pages 905-26, August.

Skees, Jerry, 2008, Innovations in Index Insurance for the Poor in Lower Income Counties Agricultural and Resource Economics Review, 37:1-15.

Suri, Tavneet, 2009, Selection and Comparative Advantage in Technology Adoption, mimeo, MIT Sloan School of Management.

Townsend, Robert, 1994, Risk and Insurance in Village India, Econometrica, 62(3), 539-591.

Walker, T. and J. Ryan, 1990, Village and Household Economics in India's Semi-Arid Tropics, John Hopkins University Press, Baltimore, Maryland.

World Bank, 2005, Managing Agricultural Production Risk: Innovations In Developing Countries, World Bank Agriculture and Rural Development Department, World Bank Press. 


\section{Appendix A: Model of insurance and production decisions}

This Appendix presents a simple illustrative model of an agricultural entrepreneur to highlight the interaction between production decisions and insurance provision. The key result is that for a risk-averse farmer, investment in risky production activities is increasing in their access to insurance against production risk. Note that, while we assume a very simple setting to build intuition, the basic results we derive extend to a much more general class of models.

\section{A. Basic setup and timing}

Consider a one-period model of a farmer with initial wealth $\mathrm{W}_{0}$ and constant absolute risk aversion (CARA) utility. The farmer has access to a risky production activity or project (e.g. sowing cash crops, or applying fertilizer), and decides at the start of the period what fraction of their wealth to devote to this risky activity. The remainder of their wealth is invested in a safe activity, which we assume for simplicity produces a real return of zero.

We denote the amount invested in the risky production activity by $\alpha$. The net return on investment (per rupee invested) is given by $\bar{R}+e$, where $\bar{R}$ is the expected return and e is a zero-mean normally distributed error term: $\mathrm{e} \sim \mathrm{N}\left(0, \sigma^{2}{ }_{\mathrm{e}}\right)$.

The farmer can partially hedge the production risk associated with the risky activity by purchasing insurance. We denote the amount spent on insurance premia by $\varphi$. The insurance payout is negatively correlated with the return on investment, but not perfectly (i.e. there is some basis risk). Net of the initial premium, the net payout on the insurance (per rupee of premium) is given by: $-\mathrm{e}+\mathrm{u}-\mu$, where $\mathrm{u} \sim \mathrm{N}\left(0, \sigma_{\mathrm{u}}^{2}\right)$. The higher is $\sigma_{\mathrm{u}}^{2}$, the greater the basis risk. We generally assume that $\mu>0$, which means that the expected insurance payout net of the premium is negative (i.e. the insurance is not actuarially fair). ${ }^{21}$

To summarize the timing: at the start of the period the farmer chooses how much to invest $(\alpha)$ and how much insurance to purchase $(\varphi)$. At the end of the period, the return on the risky production activity and the insurance payout are realized. The farmer then

\footnotetext{
${ }^{21}$ This could be because of imperfect competition amongst insurers, administrative costs of providing the insurance, or a compensation for the risk borne by the insurer.
} 
consumes their initial wealth $\mathrm{W}_{0}$ plus their net income from the investment and from insurance.

We assume the farmer faces an interior solution in equilibrium (i.e. the fraction of their wealth invested in the risky project, inclusive of any insurance purchased, is between zero and one). Finally we assume that $\mu$ is large enough so that insurance demand is positive in equilibrium.

\section{B. Optimal investment in the presence of insurance}

The farmer's objective is to maximize expected end-of period utility $\mathrm{E}\left[\mathrm{u}\left(\mathrm{W}_{1}\right)\right]$. End of period wealth $\left(\mathrm{W}_{1}\right)$ is given by the law of motion:

End of period wealth $\left(\mathrm{W}_{1}\right)=$ initial wealth $\left(\mathrm{W}_{0}\right)+$ investment return $(\mathrm{Y})+$ insurance payout (IP)

$$
=\mathrm{W}_{0}+\alpha(\overline{\mathrm{R}}+\mathrm{e})+\varphi(-\mathrm{e}+\mathrm{u}-\mu)
$$

Given our exponential-normal setup, and denoting the farmer's coefficient of absolute risk aversion by $\gamma$, the farmer's problem can be written as:

$\max _{\alpha, \varphi} \mathrm{E}\left[\mathrm{u}\left(\mathrm{W}_{1}\right)\right]=\max _{\alpha, \varphi}\left\{\mathrm{E}\left(\mathrm{W}_{1}\right)-1 / 2 \gamma \operatorname{var}\left(\mathrm{W}_{1}\right)\right\}$

where:

$\mathrm{E}\left(\mathrm{W}_{1}\right)=\mathrm{W}_{0}+\alpha \overline{\mathrm{R}}-\varphi \mu$

$\operatorname{var}\left(\mathrm{W}_{1}\right)=(\alpha-\varphi)^{2} \sigma_{\mathrm{e}}^{2}+\varphi^{2} \sigma_{\mathrm{u}}^{2}$

Taking first order conditions of [A.1] with respect to $\alpha$ and $\varphi$, and solving the resulting simultaneous equations, the optimal investment level is given by the following expression:

$$
\alpha^{*}=\frac{1}{\gamma}\left[\frac{\bar{R}-\mu}{\sigma^{2}{ }_{u}}+\frac{\bar{R}}{\sigma^{2}{ }_{e}}\right]
$$


An alternative and similar expression can be derived if we assume that the level of insurance $\varphi$ is assigned exogenously to the household, rather than being a decision variable. (This is the setting that corresponds most exactly to the design of our field experiment). In this case, optimal investment is given by the simpler expression:

$$
\alpha^{*}=\frac{1}{\gamma} \frac{\bar{R}}{\sigma_{e}^{2}}+\varphi
$$

\section{Comparative statics}

Inspecting expression [A.2] yields the following comparative statics results for the farmer's equilibrium level of investment in the risky production activity:

Proposition 1: The farmer's equilibrium investment in the risky activity $\left(\alpha^{*}\right)$ is:

A. decreasing in the expected per-unit net cost of insurance $(\mu)$.

B. decreasing in the basis risk of the insurance $\left(\sigma^{2}\right)$

C. decreasing in the variance of investment returns $\left(\sigma_{e}^{2}\right)$

D. decreasing in risk aversion $(\gamma)$

E. increasing in the expected return on investment $(\overline{\mathrm{R}})$

Proof: By taking first derivatives of [A.2] with respect to each parameter.

The same comparative statics results apply to the alternative expression for optimal investment assuming that insurance is assigned exogenously. The only difference is that part A of the Proposition instead states that investment in the risky production activity $\left(\alpha^{*}\right)$ is increasing in the exogenously determined level of insurance, $\varphi$, rather than being decreasing in the cost of insurance. 
The key result of this Proposition is that an improvement in access to insurance either an increase in the amount of exogenously provided insurance, a reduction in the cost of the insurance, or an improvement in the quality of the insurance while keeping the cost fixed - increases investment in the risky activity.

The simple intuition for these results is that the farmer's optimal level of investment trades off the high expected return of the investment against its risk. Improving access to insurance against production risk allows the farmer to reduce the background risk associated with any given investment level (i.e. to shift this risk-return frontier outwards), allowing the farmer to invest more in equilibrium. Given these results, it is also straightforward to verify that the farmer's expected income and expected utility are decreasing in the expected perunit net cost of insurance $(\mu)$, and the basis risk of the insurance $\left(\sigma_{u}^{2}\right)$, so that improving access to insurance increases expected income and welfare.

Note that since we assume exponential utility, there are no wealth effects in the model presented here. In reality, provision of insurance may affect behavior both through its riskmanagement benefits and because it increases household wealth. To control for this, in our field work we compare two groups, one of which receives insurance for free, the other of which is promised the actuarial value of the insurance for free. In other words we effectively hold fixed the wealth of the household between the treatment and control groups. 


\section{Figure 1: Cumulative Rainfall during Kharif 2009, for Phase 1 Policies}
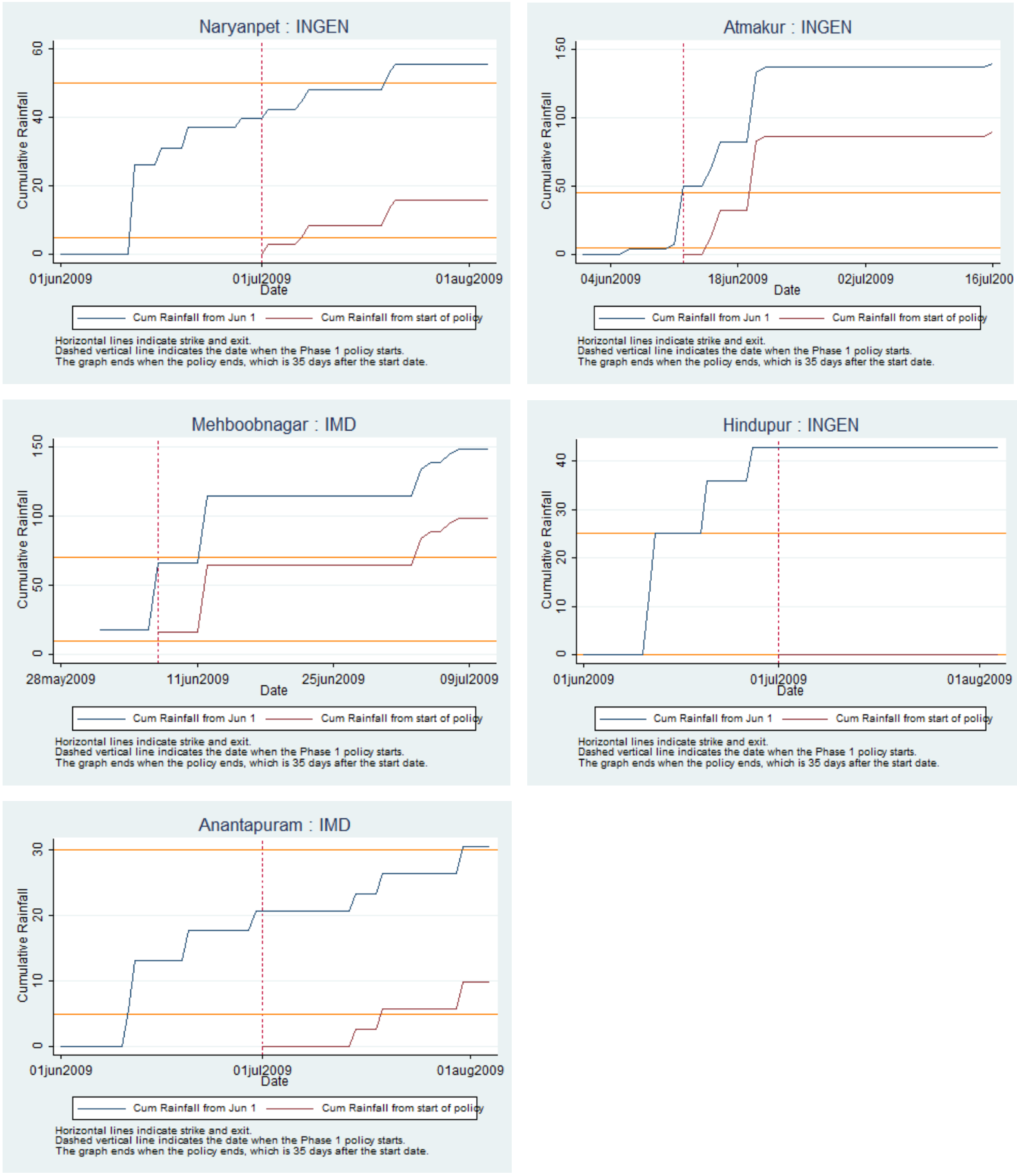
Figure 2: Cumulative density, log investment in cash crops

Y axis plots the natural $\log$ of $1+$ the amount invested in cash crops (in Rs.) for the treatment and control groups, both sorted in increasing order of cash crop investment.

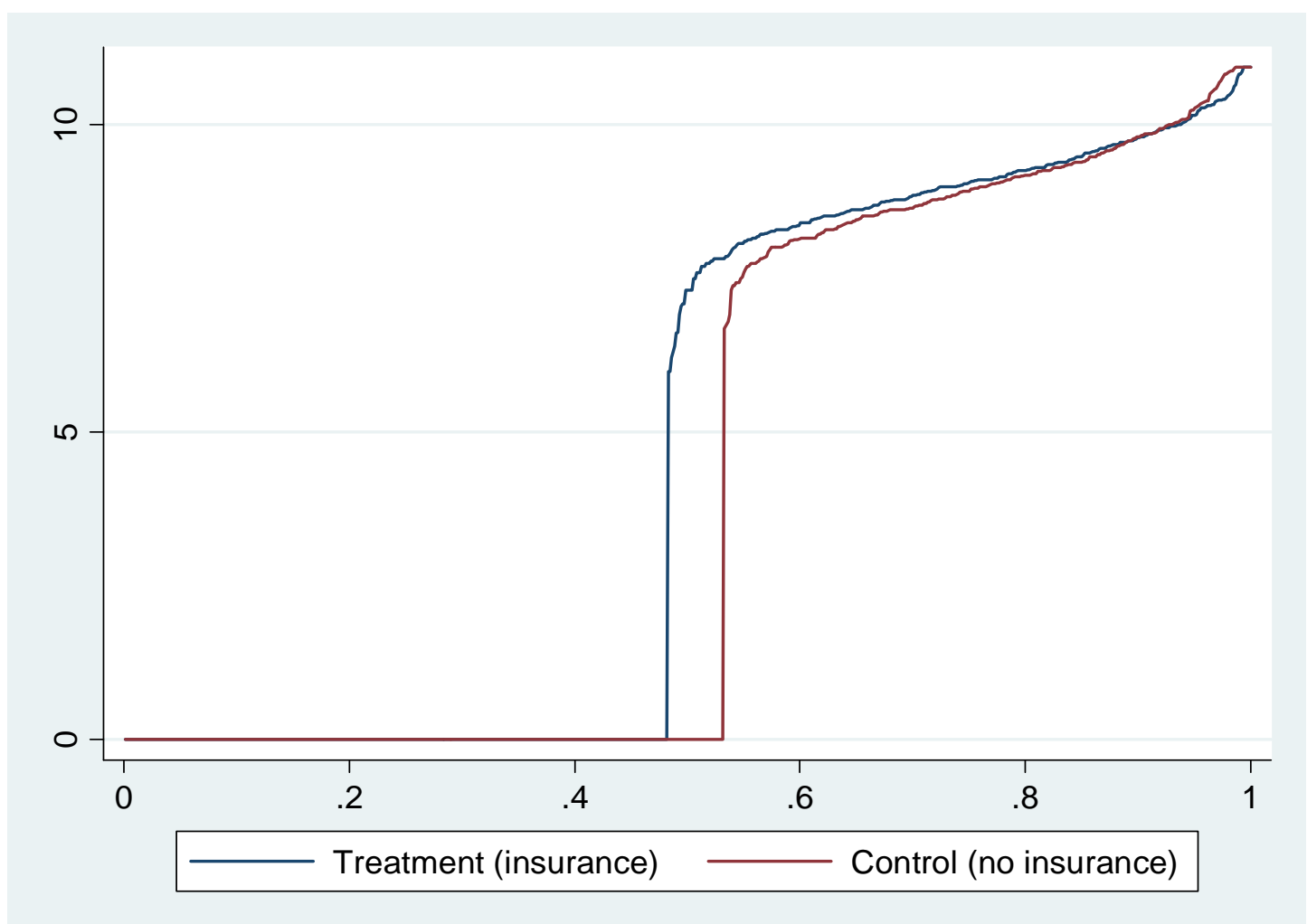


Figure 3: Effect of insurance treatment status on timing of cash crop investments

The $x$-axis of the figure plots the passage of time in 2009. The y-axis plots the effect of insurance treatment status on the probability of having planted cash crops by the date in question. The three red vertical lines correspond to the start and end of the period in which insurance was distributed to farmers.

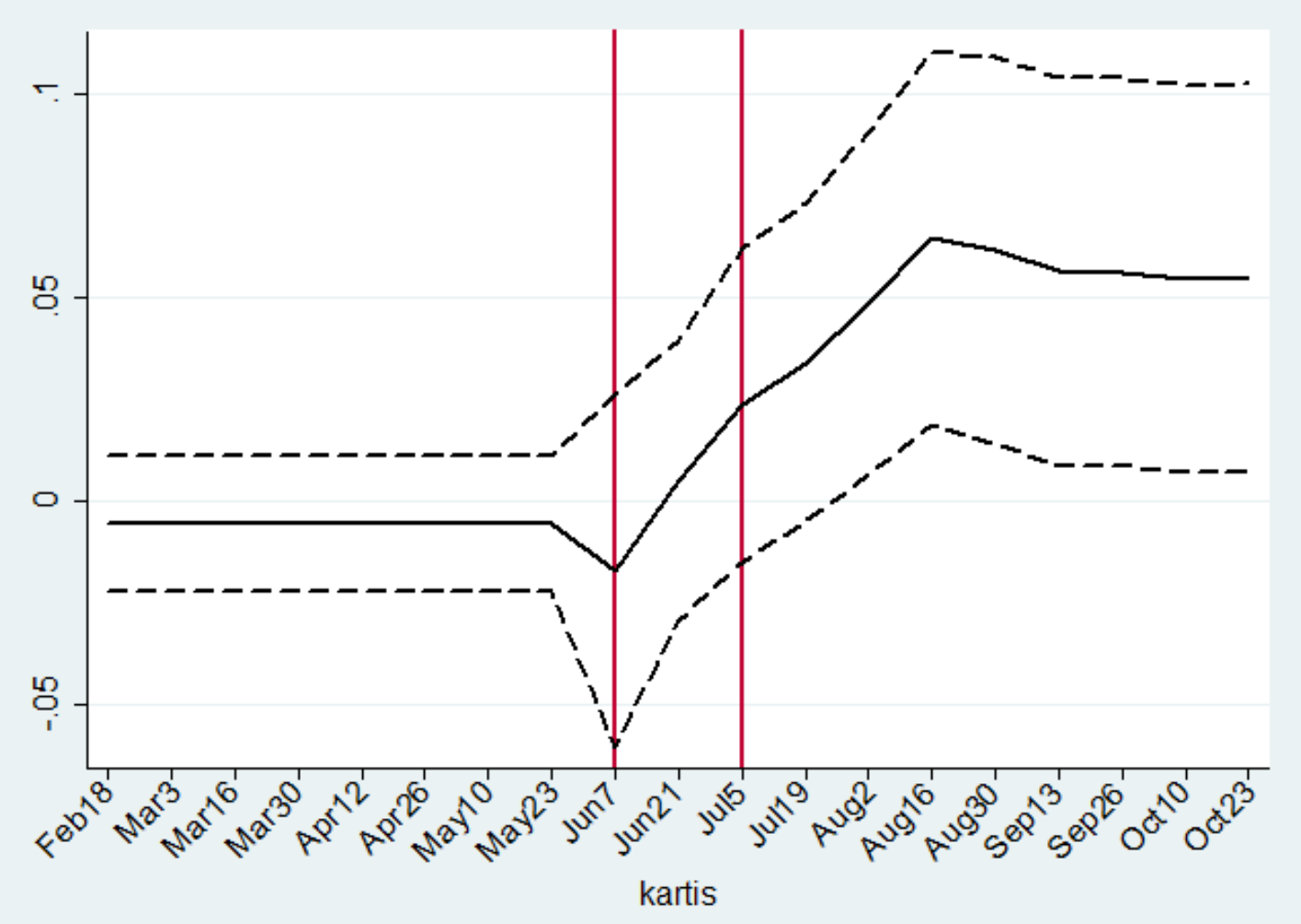


Table 1: Household Summary Statistics

\begin{tabular}{|c|c|c|c|c|c|c|}
\hline Variable & $\mathrm{N}$ & Mean & SD & $\mathrm{p} 10$ & $\mathrm{p} 50$ & $\overline{\mathrm{p} 90}$ \\
\hline \multicolumn{7}{|l|}{ A. Demographic Characteristics } \\
\hline Household size & 1,479 & 5.35 & 2.28 & 3 & 5 & 8 \\
\hline Number of children 6 years old or younger & 1,479 & 0.20 & 0.54 & 0 & 0 & 1 \\
\hline Number of children 18 years old or younger & 1,479 & 1.70 & 1.51 & 0 & 2 & 4 \\
\hline Age of household head (Years) & 1,479 & 49.60 & 12.40 & 35 & 50 & 65 \\
\hline Highest level of schooling completed by HH (Years) & 1,479 & 3.75 & 4.76 & 0 & 0 & 11 \\
\hline Household head is unschooled ( 1 = "Yes") & 1,479 & 0.54 & 0.50 & & & \\
\hline Household head able to read (1 = "Yes") & 1,479 & 0.44 & 0.50 & & & \\
\hline Household head able to write ( 1 = "Yes") & 1,479 & 0.41 & 0.50 & & & \\
\hline \multicolumn{7}{|l|}{ B. Livestock (as of June 2009) } \\
\hline N. of large animals owned, i.e. buffalos, cows and oxen & 1,479 & 2.25 & 3.01 & 0 & 2 & 6 \\
\hline N. of small animals owned, i.e. goats, sheep, chicken, pigs & 1,479 & 5.23 & 22.22 & 0 & 0 & 10 \\
\hline Total market value of livestock owned (Rs.) & 1,479 & 34,263 & 58,623 & 0 & 20,000 & 80,000 \\
\hline \multicolumn{7}{|l|}{ C. Savings and Credit } \\
\hline Total amount of savings, all sources (Rs.) & 1,479 & 21,353 & 29,472 & 0 & 11,000 & 56,980 \\
\hline Amount of savings with bank or post office (Rs.) & 1,479 & 1,575 & 5,640 & 0 & 0 & 4,000 \\
\hline Amount of savings in cash at home (Rs.) & 1,479 & 1,715 & 3,228 & 0 & 600 & 5,000 \\
\hline Amount of savings in jewelry (Rs.) & 1,479 & 13,335 & 20,589 & 0 & 5,000 & 32,000 \\
\hline Amount of savings with SHG or other group (Rs.) & 1,479 & 2,152 & 4,910 & 0 & 720 & 5,000 \\
\hline Amount of other savings (Rs.) & 1,479 & 2,576 & 11,427 & 0 & 0 & 3,600 \\
\hline Total amount of credit owed, all sources (Rs.) & 1,479 & 41,644 & 50,498 & 8,000 & 29,000 & 87,000 \\
\hline Amount of credit from bank (Rs.) & 1,479 & 20,414 & 31,823 & 0 & 15,000 & 45,000 \\
\hline Amount of credit from family and friends (Rs.) & 1,479 & 6,406 & 19,505 & 0 & 0 & 20,000 \\
\hline Amount of credit from MFIs (Rs.) & 1,479 & 692 & 3,684 & 0 & 0 & 0 \\
\hline Amount of credit from moneylenders (Rs.) & 1,479 & 12,747 & 30,840 & 0 & 0 & 35,000 \\
\hline Amount of credit from other sources of credit (Rs.) & 1,479 & 1,386 & 5,079 & 0 & 0 & 5,000 \\
\hline \multicolumn{7}{|l|}{ D. Other Assets } \\
\hline House type: strong structure (1 = "Yes") & 1,479 & 0.54 & 0.50 & & & \\
\hline House type: semi-strong structure ( 1 = "Yes") & 1,479 & 0.33 & 0.47 & & & \\
\hline House type: weak structure (1 = "Yes") & 1,479 & 0.13 & 0.33 & & & \\
\hline Number or rooms in the house & 1,479 & 2.63 & 1.34 & 1 & 2 & 4 \\
\hline Estimated value of the house if owned (Rs.) & 1,479 & 117,221 & 165,962 & 25,000 & 70,000 & 220,000 \\
\hline Total area of agricultural land (Acres) & 1,479 & 5.37 & 5.47 & 2 & 4 & 10 \\
\hline Estimated value of agricultural land (Rs.) & 1,479 & 508,519 & $1,463,349$ & 70,000 & 240,000 & 980,000 \\
\hline Est. value of non-agricultural land and other assets (Rs.) & 1,479 & 8,642 & 49,500 & 0 & 0 & 20,000 \\
\hline
\end{tabular}

Notes: This table reports the summary statistics for the sample, which includes the 1479 individuals that participated in both the baseline and follow-up surveys. The variables reported in Section $\mathrm{C}$ were collected during the baseline survey conducted between April and June 2009. Variables in Section A, B and D were collected during the follow up survey in November 2009, but respondents were asked to report answers as of June 2009. 
Table 2: Investment in Kharif 2009

\begin{tabular}{|c|c|c|c|c|c|c|c|c|c|c|c|c|}
\hline & \multicolumn{6}{|c|}{ All Crops } & \multicolumn{6}{|c|}{ Cash Crops } \\
\hline & Amount & & & & & & Amount & & & & & \\
\hline & $>0$ & Mean & SD & $\mathrm{p} 10$ & $\mathrm{p} 50$ & p90 & $>0$ & Mean & SD & p10 & $\mathrm{p} 50$ & p90 \\
\hline \multicolumn{13}{|l|}{ Land use: } \\
\hline Total cultivated land & 0.93 & 4.00 & 3.59 & 1.00 & 3.00 & 8.00 & 0.48 & 1.92 & 2.98 & 0.00 & 0.00 & 5.00 \\
\hline In which Kartis did farmer plant? & & 15.68 & 2.78 & 13.00 & 16.00 & 18.00 & & 15.26 & 2.29 & 13.00 & 15.00 & 18.00 \\
\hline Did farmer replant crop this Kharif? (1="Yes" ) & & & & & & & 0.05 & & & & & \\
\hline Did farmer abandon crop this Kharif? (1="Yes") & & & & & & & 0.18 & & & & & \\
\hline
\end{tabular}

\begin{tabular}{|c|c|c|c|c|c|c|c|c|c|c|c|c|}
\hline \multicolumn{13}{|l|}{ Total amount spent on inputs } \\
\hline Hybrid seeds & 0.63 & 1,774 & 3,679 & 0 & 750 & 4,000 & & & & & & \\
\hline Improved seeds & 0.59 & 3,871 & 6,112 & 0 & 1,500 & 11,000 & & & & & & \\
\hline Fertilizer & 0.95 & 3,156 & 3,382 & 800 & 2,000 & 7,000 & & & & & & \\
\hline Manure & 0.74 & 3,237 & 4,261 & 0 & 2,000 & 8,000 & & & & & & \\
\hline Pesticide & 0.64 & 1,438 & 2,656 & 0 & 600 & 4,000 & & & & & & \\
\hline Irrigation & 0.26 & 1,039 & 2,822 & 0 & 0 & 3,550 & & & & & & \\
\hline Hiring tractors or other implements & 0.91 & 3,541 & 3,482 & 600 & 3,000 & 7,000 & & & & & & \\
\hline Manual labor & 0.95 & 3,069 & 3,432 & 500 & 2,000 & 6,000 & & & & & & \\
\hline Bullock labor & 0.68 & 1,299 & 1,933 & 0 & 1,000 & 3,000 & & & & & & \\
\hline Total amount spent, all inputs & 0.98 & 22,424 & 19,935 & 6,300 & 16,600 & 44,500 & & & & & & \\
\hline \multicolumn{13}{|l|}{ Market value used for all crops: } \\
\hline Hybrid seeds & 0.63 & 1,852 & 3,961 & 0 & 800 & 4,450 & 0.17 & 476 & 2,480 & 0 & 0 & $\overline{1,200}$ \\
\hline Improved seeds & 0.56 & 3,779 & 6,012 & 0 & 1,200 & 11,000 & 0.31 & 2,402 & 5,537 & 0 & 0 & 8,000 \\
\hline Fertilizer & 0.93 & 3,208 & 3,873 & 500 & 2,000 & 7,000 & 0.45 & 1,098 & 1,973 & 0 & 0 & 3,000 \\
\hline Manure & 0.73 & 3,182 & 4,213 & 0 & 2,000 & 8,000 & 0.35 & 1,360 & 3,112 & 0 & 0 & 4,500 \\
\hline Pesticide & 0.64 & 1,447 & 2,659 & 0 & 600 & 4,000 & 0.30 & 544 & 1,823 & 0 & 0 & 1,500 \\
\hline Irrigation & 0.25 & 1,025 & 2,779 & 0 & 0 & 3,550 & & & & & & \\
\hline Hiring tractors or other implements & 0.91 & 3,545 & 3,552 & 500 & 3,000 & 7,000 & & & & & & \\
\hline Manual labor & 0.94 & 3,044 & 3,453 & 500 & 2,000 & 6,000 & & & & & & \\
\hline Bullock labor & 0.68 & 1,295 & 1,943 & 0 & 1,000 & 3,000 & & & & & & \\
\hline Total market value used, inputs $1-5$ & 0.96 & 13,467 & 13,758 & 2,600 & 9,500 & 28,700 & 0.49 & 6,123 & 11,096 & 0 & 0 & 17,800 \\
\hline Total market value used, all inputs & 0.97 & 22,377 & 20,206 & 5,550 & 16,700 & 45,000 & & & & & & \\
\hline
\end{tabular}

Notes: Data were collected during the follow up survey conducted in November 2009. The sample includes the 1479 individuals that participated in both the baseline and followup surveys. All reported monetary values are in Rupees. In November 2009, when this survey was conducted, the average exchange rate between US Dollars and Indian Rupees was of Rs. 47 per dollar. The statistics report the mean of an indicator variable for whether the quantity listed is greater than zero, and the mean, standard deviation and percentiles of the values. 
Table 3. Effects of insurance on agricultural investments

\begin{tabular}{|c|c|c|c|c|c|}
\hline \multirow[t]{2}{*}{ Crop types: } & \multicolumn{2}{|c|}{ All crop types } & \multicolumn{2}{|c|}{ Cash crops only } & \multirow[b]{2}{*}{ Estimator } \\
\hline & $\begin{array}{l}\text { Insurance dummy } \\
\text { (marginal effect) }\end{array}$ & pseudo- $\mathrm{R}^{2}$ & $\begin{array}{c}\text { Insurance dummy } \\
\text { (marginal effect) }\end{array}$ & pseudo- $\mathrm{R}^{2}$ & \\
\hline \multicolumn{6}{|l|}{ A. Without household covariates } \\
\hline Any ag. inputs used (=1 if yes) & $\begin{array}{c}0.016 \\
(0.012)\end{array}$ & 0.074 & $\begin{array}{c}0.060 * * \\
(0.029)\end{array}$ & 0.213 & probit \\
\hline $\ln (1+$ land under cultivation, acres $)$ & $\begin{array}{c}0.029 \\
(0.034)\end{array}$ & 0.05 & $\begin{array}{l}0.163 * * \\
(0.070)\end{array}$ & 0.155 & tobit \\
\hline $\ln (1+$ ag. inputs used, Rs. $)$ & $\begin{array}{c}0.082 \\
(0.087)\end{array}$ & 0.032 & $\begin{array}{c}0.800 * * \\
(0.387)\end{array}$ & 0.092 & tobit \\
\hline $\ln (1+$ ag. inputs purchased, Rs.) & $\begin{array}{c}0.05 \\
(0.079)\end{array}$ & 0.032 & & & tobit \\
\hline \multicolumn{6}{|l|}{ B. With household covariates } \\
\hline Any ag. inputs used (=1 if yes) & $\begin{array}{c}0.013 \\
(0.010)\end{array}$ & 0.133 & $\begin{array}{l}0.065^{* * *} \\
(0.030)\end{array}$ & 0.222 & probit \\
\hline $\ln (1+$ land under cultivation, acres $)$ & $\begin{array}{c}0.041 \\
(0.031)\end{array}$ & 0.133 & $\begin{array}{l}0.176^{* * *} \\
(0.067)\end{array}$ & 0.170 & tobit \\
\hline $\ln (1+$ ag. inputs used, Rs. $)$ & $\begin{array}{r}0.112 \\
(0.083)\end{array}$ & 0.062 & $\begin{array}{l}0.862^{* *} \\
(0.383)\end{array}$ & 0.096 & tobit \\
\hline $\ln (1+$ ag. inputs purchased, Rs.) & $\begin{array}{r}0.079 \\
(0.074) \\
\end{array}$ & 0.065 & & & \\
\hline $\mathrm{N}$ & 1479 & & 1479 & & \\
\hline Village dummies & yes & & yes & & \\
\hline
\end{tabular}

Note: Data were collected during the baseline and follow up surveys conducted in 2009. The sample includes the 1479 individuals that participated in both the baseline and follow-up surveys. Symbols *, **, *** denote significance at the 10,5 and 1 percent level, respectively. The dependent variables are: a dummy variable equal to one if the household used any agricultural inputs, the log of (1+ the amount of land under cultivation), the log of $(1+$ the value of inputs used), and the $\log (1+$ the market value of inputs purchased). The column to the left reports regression results for all crop types, while the column to the right reports regression results for cash crops only. Cash crops are defined as castor in Mahbubnagar and groundnut in Anantapur. The top panel reports results for the main specification, while the panel at the bottom includes household covariates as a robustness check. Household covariates included in this specification are the age of the household head, the log of the number of years of schooling of household head and the wealth index. The regressions include indicator variables for each village. 
Table 4. Cash crop treatment effects disaggregated by investment type

\begin{tabular}{|c|c|c|c|c|}
\hline \multirow[t]{2}{*}{ Dependent variable: } & \multicolumn{2}{|c|}{ Dummy: Investment $>0$} & \multicolumn{2}{|c|}{$\ln (1+$ investment, Rs. $)$} \\
\hline & $\begin{array}{l}\text { Insurance dummy } \\
\text { (marginal effect) }\end{array}$ & pseudo- $\mathrm{R}^{2}$ & $\begin{array}{l}\text { Insurance dummy } \\
\text { (marginal effect) }\end{array}$ & pseudo- $\mathrm{R}^{2}$ \\
\hline \multicolumn{5}{|c|}{$\begin{array}{l}\text { Agricultural input used } \\
\text { (Rs.): }\end{array}$} \\
\hline Hybrid seeds & $\begin{array}{r}0.024 \\
(0.024)\end{array}$ & 0.202 & $\begin{array}{r}0.712 \\
(0.706)\end{array}$ & 0.144 \\
\hline Improved seeds & $\begin{array}{r}0.025 \\
(0.029)\end{array}$ & 0.316 & $\begin{array}{r}0.383 \\
(0.474)\end{array}$ & 0.17 \\
\hline Fertilizer & $\begin{array}{r}0.045 \\
(0.029)\end{array}$ & 0.214 & $\begin{array}{r}0.569 \\
(0.360)\end{array}$ & 0.086 \\
\hline Manure & $\begin{array}{r}0.020 \\
(0.027)\end{array}$ & 0.203 & $\begin{array}{r}0.362 \\
(0.469)\end{array}$ & 0.093 \\
\hline Pesticide & $\begin{array}{l}0.054 * * \\
(0.026)\end{array}$ & 0.254 & $\begin{array}{l}0.932 * * \\
(0.447)\end{array}$ & 0.134 \\
\hline $\mathrm{N}$ & 1479 & & 1479 & \\
\hline Village dummies & yes & & yes & \\
\hline Estimator & Probit & & Tobit & \\
\hline
\end{tabular}

Note: Data was collected during the baseline and follow up surveys conducted in 2009. The sample includes the 1479 individuals that participated in both the baseline and follow-up surveys. Symbols *, $* *, * * *$ denote significance at the 10,5 and 1 percent level, respectively. Dependent variables are listed in the first column to the left. Cash crops are defined as castor in Mahbubnagar and groundnut in Anantapur. The regressions include village fixed effects. 
Table 5. Interaction effects

\begin{tabular}{|c|c|c|c|c|c|c|c|c|c|}
\hline \multirow[t]{2}{*}{ Dependent variable: } & \multicolumn{3}{|c|}{ Dummy: Investment in cash crops $>0$} & \multicolumn{3}{|c|}{$\ln (1+$ investment in cash crops, Rs.) } & \multicolumn{3}{|c|}{$\ln (1+$ land cultivated for cash crops) } \\
\hline & $\begin{array}{c}\text { Treatment } \\
\text { (1=yes) }\end{array}$ & $\begin{array}{l}\text { Hosehold } \\
\text { covariate: }\end{array}$ & $\begin{array}{r}\text { Treatment } \\
\text { x covariate }\end{array}$ & $\begin{array}{c}\text { Treatment } \\
(1=\text { yes })\end{array}$ & $\begin{array}{l}\text { Hosehold } \\
\text { covariate: }\end{array}$ & $\begin{array}{c}\text { Treatment } \\
\text { x covariate }\end{array}$ & $\begin{array}{c}\text { Treatment } \\
\text { (1=yes) }\end{array}$ & $\begin{array}{l}\text { Hosehold } \\
\text { covariate: }\end{array}$ & $\begin{array}{c}\text { Treatment } \\
\text { x covariate }\end{array}$ \\
\hline \multicolumn{10}{|l|}{ Interaction variable is: } \\
\hline \multicolumn{10}{|l|}{ Wealth measures } \\
\hline Wealth index: principal component & $\begin{array}{l}0.062 * * \\
(0.029)\end{array}$ & $\begin{array}{l}0.041^{* * *} \\
(0.013)\end{array}$ & $\begin{array}{r}-0.012 \\
(0.018)\end{array}$ & $\begin{array}{l}0.180 * * * \\
(0.068)\end{array}$ & $\begin{array}{l}0.171^{* * *} \\
(0.030)\end{array}$ & $\begin{array}{r}-0.035 \\
(0.042)\end{array}$ & $\begin{array}{l}0.871 * * \\
(0.388)\end{array}$ & $\begin{array}{l}0.641^{* * * *} \\
(0.168)\end{array}$ & $\begin{array}{r}-0.220 \\
(0.235)\end{array}$ \\
\hline $\ln (1+$ landholdings $)$ & $\begin{array}{r}0.026 \\
(0.096)\end{array}$ & $\begin{array}{l}0.165^{* * *} \\
(0.038)\end{array}$ & $\begin{array}{r}0.018 \\
(0.055)\end{array}$ & $\begin{array}{r}0.118 \\
(0.212)\end{array}$ & $\begin{array}{l}0.755^{* * *} \\
(0.084)\end{array}$ & $\begin{array}{r}0.013 \\
(0.119)\end{array}$ & $\begin{array}{r}0.636 \\
(1.241)\end{array}$ & $\begin{array}{l}2.615^{* * *} \\
(0.475)\end{array}$ & $\begin{array}{r}0.052 \\
(0.666)\end{array}$ \\
\hline \multicolumn{10}{|l|}{ Education measures } \\
\hline Household head can read ( 1 = yes) & $\begin{array}{r}-0.001 \\
(0.039)\end{array}$ & $\begin{array}{r}-0.019 \\
(0.043)\end{array}$ & $\begin{array}{l}0.147 * * \\
(0.059)\end{array}$ & $\begin{array}{r}-0.042 \\
(0.093)\end{array}$ & $\begin{array}{r}-0.077 \\
(0.102)\end{array}$ & $\begin{array}{l}0.469 * * * \\
(0.141)\end{array}$ & $\begin{array}{r}-0.048 \\
(0.523)\end{array}$ & $\begin{array}{l}-0.155 \\
(0.575)\end{array}$ & $\begin{array}{l}1.959 * * \\
(0.779)\end{array}$ \\
\hline \multicolumn{10}{|l|}{ Other measures } \\
\hline SD of exp. yield (kg/acre) of cash crops & $\begin{array}{c}0.090 * \\
(0.047)\end{array}$ & $\begin{array}{r}0.001 \\
(0.001)\end{array}$ & $\begin{array}{r}-0.001 \\
(0.001)\end{array}$ & $\begin{array}{l}0.173 \\
(0.110)\end{array}$ & $\begin{array}{r}-0.000 \\
(0.002)\end{array}$ & $\begin{array}{r}-0.000 \\
(0.002)\end{array}$ & $\begin{array}{l}1.269 * * \\
(0.591)\end{array}$ & $\begin{array}{r}0.007 \\
(0.008)\end{array}$ & $\begin{array}{r}-0.010 \\
(0.009)\end{array}$ \\
\hline Insurance Knowledge Index & $\begin{array}{c}0.067^{*} \\
(0.039)\end{array}$ & $\begin{array}{l}-0.065^{* *} \\
(0.026)\end{array}$ & $\begin{array}{r}0.022 \\
(0.034)\end{array}$ & $\begin{array}{c}0.150 * \\
(0.088)\end{array}$ & $\begin{array}{l}-0.129 * * \\
(0.065)\end{array}$ & $\begin{array}{r}0.034 \\
(0.089)\end{array}$ & $\begin{array}{r}0.792 \\
(0.482)\end{array}$ & $\begin{array}{l}-0.921^{* *} \\
(0.380)\end{array}$ & $\begin{array}{r}0.244 \\
(0.504)\end{array}$ \\
\hline Has heard of rainfall insurance ( $1=$ Yes) & & $\begin{array}{l}0.292 * * * \\
(0.110)\end{array}$ & $\begin{array}{r}-0.104 \\
(0.143)\end{array}$ & & $\begin{array}{c}0.537 * \\
(0.292)\end{array}$ & $\begin{array}{r}-0.105 \\
(0.377)\end{array}$ & & $\begin{array}{l}4.182^{* *} \\
(1.702)\end{array}$ & $\begin{array}{r}-1.003 \\
(2.137)\end{array}$ \\
\hline Estimator & & Probit & & & Tobit & & & Tobit & \\
\hline
\end{tabular}

Note: Data was collected during the baseline and follow up surveys conducted in 2009. The sample includes the 1479 individuals that participated in both the baseline and follow-up surveys. The sample is equal to 1405 for probit regression, and 1479 for the tobit regressions. Symbols $*{ }^{* *}, * * *$ denote significance at the 10,5 and 1 percent level, respectively. The table reports marginal effects for the treatment dummy, for the coefficient for the main interaction term, and for the interaction between the treatment dummy and the main effect. Each specification includes a different main effect and interaction term, reported in the first column to the left. The specification that includes the insurance knowledge index additionally includes a dummy variable equal to one if the respondent has never heard of rainfall insurance, and its interaction term. Cash crops are defined as castor in Mahbubnagar and groundnut in Anantapur. The regressions include an indicator variable for each village. 
Table 6: Self-Reported Effects of Rainfall Insurance on Agricultural Investments

\begin{tabular}{lcccc}
\hline \hline Variable & $\mathrm{N}$ & More & No Change & Less \\
\hline Effect of rainfall insurance on: & & & & \\
The amount of: & 743 & $50 \%$ & $36 \%$ & $14 \%$ \\
$\quad$ Fertilizer & 743 & $41 \%$ & $43 \%$ & $16 \%$ \\
$\quad$ Seeds & 743 & $32 \%$ & $41 \%$ & $27 \%$ \\
$\quad$ Pesticides & 743 & $23 \%$ & $48 \%$ & $29 \%$ \\
$\quad$ Bullock labor & 743 & $35 \%$ & $42 \%$ & $23 \%$ \\
$\quad$ Hired labor & 743 & $26 \%$ & $52 \%$ & $22 \%$ \\
$\quad$ Funds borrowed to finance agri inputs & & & & \\
& & & & \\
The timing of initial planting & 743 & $26 \%$ & & \\
$\quad$ Earlier & 743 & $69 \%$ & & \\
$\quad$ No change & 743 & $5 \%$ & & \\
Later & & & & \\
& & & \\
The decision of whether to abandon crops & 743 & $26 \%$ & & \\
Against & 743 & $67 \%$ & & \\
No change & 743 & $7 \%$ & \\
$\quad$ Towards & & &
\end{tabular}

Notes: This table reports self-reported investment decisions among farmers in the treatment group with data from a follow-up survey conducted in November 2009. 
Table 7: BDM Experiment Policy Details

Phase I

\begin{tabular}{|c|c|c|c|c|c|c|c|c|c|c|c|c|c|c|c|c|}
\hline \multirow[b]{2}{*}{ Station } & \multicolumn{5}{|c|}{ Actual Policy } & \multicolumn{5}{|c|}{ Policy More Likely to Pay Maximum } & \multicolumn{5}{|c|}{ Policy Pays Less per mm Shortfall } & \multirow{2}{*}{$\begin{array}{c}\text { Policy from Distant Station } \\
\text { Reference Station } \\
\end{array}$} \\
\hline & $\begin{array}{l}\text { Strike } \\
(\mathbf{m m})\end{array}$ & $\begin{array}{r}\text { Exit } \\
(\mathrm{mm})\end{array}$ & $\begin{array}{c}\text { Per mm } \\
\text { (Rs) }\end{array}$ & $\begin{array}{c}\text { Premium } \\
\text { (Rs) }\end{array}$ & $\begin{array}{c}\text { Exp. } \\
\text { Payout }\end{array}$ & $\begin{array}{l}\text { Strike } \\
(\mathbf{m m})\end{array}$ & $\begin{array}{r}\text { Exit } \\
(\mathrm{mm})\end{array}$ & $\begin{array}{c}\text { Per mm } \\
\text { (Rs) }\end{array}$ & $\begin{array}{c}\text { Premium } \\
\text { (Rs) }\end{array}$ & $\begin{array}{c}\text { Exp. } \\
\text { Payout }\end{array}$ & $\begin{array}{l}\text { Strike } \\
(\mathbf{m m})\end{array}$ & $\begin{array}{r}\text { Exit } \\
(\mathrm{mm})\end{array}$ & $\begin{array}{c}\text { Per mm } \\
\text { (Rs) }\end{array}$ & $\begin{array}{c}\text { Premium } \\
\text { (Rs) }\end{array}$ & $\begin{array}{c}\text { Exp. } \\
\text { Payout }\end{array}$ & \\
\hline Atmakur & 48 & 0 & 10 & 110 & - & 48 & 5 & 10 & 110 & - & 48 & 0 & 5 & 110 & - & Mehboobnagar \\
\hline Anantpuram & 25 & 6 & 10 & 110 & - & 25 & 10 & 10 & 110 & - & 25 & 6 & 5 & 110 & - & Hindpur \\
\hline Hindupur & 25 & 5 & 10 & 80 & - & 25 & 10 & 10 & 80 & - & 25 & 5 & 5 & 80 & - & Anantpuram \\
\hline Mehboobnagar & 70 & 0 & 10 & 80 & - & 70 & 5 & 10 & 80 & - & 70 & 0 & 5 & 80 & - & Narayanpet \\
\hline Narayanpet & 38 & 0 & 10 & 100 & - & 38 & 5 & 10 & 100 & - & 38 & 0 & 5 & 100 & - & Atmakur \\
\hline
\end{tabular}

Phase II

\begin{tabular}{|c|c|c|c|c|c|c|c|c|c|c|c|c|c|c|c|c|}
\hline \multirow[b]{2}{*}{ Station } & \multicolumn{5}{|c|}{ Actual Policy } & \multicolumn{5}{|c|}{ Policy More Likely to Pay Maximum } & \multicolumn{5}{|c|}{ Policy Pays Less per mm Shortfall } & \multirow{2}{*}{$\begin{array}{c}\text { Policy from Distant Station } \\
\text { Reference Station }\end{array}$} \\
\hline & $\begin{array}{l}\text { Strike } \\
(\mathrm{mm})\end{array}$ & $\begin{array}{c}\text { Exit } \\
(\mathbf{m m})\end{array}$ & $\begin{array}{l}\text { Per mm } \\
\text { (Rs) }\end{array}$ & $\begin{array}{l}\text { Premium } \\
\text { (Rs) }\end{array}$ & $\begin{array}{c}\text { Exp. } \\
\text { Payout }\end{array}$ & $\begin{array}{l}\text { Strike } \\
(\mathrm{mm})\end{array}$ & $\begin{array}{c}\text { Exit } \\
(\mathrm{mm})\end{array}$ & $\begin{array}{l}\text { Per mm } \\
\text { (Rs) }\end{array}$ & $\begin{array}{l}\text { Premium } \\
\text { (Rs) }\end{array}$ & $\begin{array}{c}\text { Exp. } \\
\text { Payout }\end{array}$ & $\begin{array}{l}\text { Strike } \\
(\mathbf{m m})\end{array}$ & $\begin{array}{c}\text { Exit } \\
(\mathrm{mm})\end{array}$ & $\begin{array}{l}\text { Per mm } \\
\text { (Rs) }\end{array}$ & $\begin{array}{l}\text { Premium } \\
\text { (Rs) }\end{array}$ & $\begin{array}{c}\text { Exp. } \\
\text { Payout }\end{array}$ & \\
\hline Atmakur & 40 & 5 & 10 & 100 & - & 40 & 10 & 10 & 100 & - & 40 & 5 & 5 & 100 & - & Mehboobnagar \\
\hline Anantpuram & 30 & 0 & 10 & 110 & 44.4 & 30 & 5 & 10 & 110 & 110.1 & 30 & 0 & 5 & 110 & 22.2 & Hindupur \\
\hline Hindupur & 15 & 0 & 10 & 120 & - & 15 & 5 & 10 & 120 & - & 15 & 0 & 5 & 120 & - & Anantpuram \\
\hline Mehboobnagar & 50 & 10 & 10 & 80 & 53.7 & 50 & 15 & 10 & 80 & 93.8 & 50 & 10 & 5 & 80 & 42.5 & Narayanpet \\
\hline Narayanpet & 53 & 5 & 10 & 100 & - & 53 & 10 & 10 & 100 & - & 53 & 5 & 5 & 100 & - & Atmakur \\
\hline
\end{tabular}


Table 8: Summary Statistics, Bid per Policy

Average bid, by orderig:

\begin{tabular}{lcr}
\hline \hline & Ordering 1 & Ordering 2 \\
\cline { 2 - 3 } Bid Type & Mean & \multicolumn{2}{c}{ Mean } \\
\hline Actual policy & 69.0 & 67.9 \\
Policy more likely to pay maximum amount (exit) & 79.8 & 78.8 \\
Policy pays less per mm shortfall (mm) & 56.7 & 56.4 \\
Policy from distant rainfall station (basis risk) & 38.9 & 39.1
\end{tabular}

Average bid, summary statistics:

\begin{tabular}{|c|c|c|c|c|c|c|c|c|}
\hline \multirow[b]{2}{*}{ Bid Type } & \multicolumn{8}{|c|}{ All Bids } \\
\hline & Mean & St Dev. & p1 & p5 & $\mathrm{p} 50$ & p95 & p99 & $\mathrm{N}$ \\
\hline Actual policy & 68.4 & 20.9 & 8 & 30 & 70 & 100 & 100 & 1978 \\
\hline Policy more likely to pay maximum amount (exit) & 79.3 & 22.1 & 10 & 40 & 80 & 110 & 110 & 1978 \\
\hline Policy pays less per mm shortfall (mm) & 56.5 & 18.2 & 6 & 30 & 55 & 90 & 100 & 1978 \\
\hline Policy from distant rainfall station (basis risk) & 39.0 & 18.1 & 5 & 20 & 35 & 78 & 86 & 1978 \\
\hline
\end{tabular}

Notes: These tables report the average bid per policy. Each policy was assigned to a random ordering, and the Ordering 1 and Ordering 2 columns report the average bids with respect to each. All monetary values are in Indian rupees. 
Table 9: Regression Results of Bids on Policy Characteristics

\begin{tabular}{|c|c|c|c|c|}
\hline & Phase I & Phase II & All & All \\
\hline & $(1)$ & $(2)$ & (3) & (4) \\
\hline VARIABLES & Bid & Bid & Bid & Bid \\
\hline Policy pays less per mm of deviation (mm) & $\begin{array}{c}-13.23^{* * *} \\
(0.555)\end{array}$ & $\begin{array}{c}-11.48^{* * *} \\
(0.356)\end{array}$ & $\begin{array}{c}-11.90 * * * \\
(0.302)\end{array}$ & $\begin{array}{c}-11.90 * * * \\
(0.302)\end{array}$ \\
\hline More likely policy pays maximum amount (exit) & $\begin{array}{c}11.33^{* * *} \\
(0.196)\end{array}$ & $\begin{array}{c}10.71^{* * *} \\
(0.173)\end{array}$ & $\begin{array}{c}10.86^{* * *} \\
(0.140)\end{array}$ & $\begin{array}{c}10.86^{* * *} \\
(0.140)\end{array}$ \\
\hline Policy is from a distant rainfall station (basis risk) & $\begin{array}{c}-30.69 * * * \\
(0.712)\end{array}$ & $\begin{array}{c}-29.06 * * * \\
(0.487)\end{array}$ & $\begin{array}{c}-29.45^{* * *} \\
(0.408)\end{array}$ & $\begin{array}{c}-29.45^{* * *} \\
(0.408)\end{array}$ \\
\hline Phase 2 Policy & & & $\begin{array}{c}-5.001 * * * \\
(0.881)\end{array}$ & $\begin{array}{c}-5.050 * * * \\
(0.862)\end{array}$ \\
\hline New Participants & & & & $\begin{array}{c}6.328 * * * \\
(1.032)\end{array}$ \\
\hline Policy Ordering 2 & & & & $\begin{array}{c}-0.484 \\
(0.792)\end{array}$ \\
\hline Income distribution ( $>25 \%$ \& <55\%) & & & & $\begin{array}{l}2.021^{*} \\
(1.152)\end{array}$ \\
\hline Income distribution (>50\% \& <75\%) & & & & $\begin{array}{c}2.842 * * \\
(1.263)\end{array}$ \\
\hline Income distribution (>75\%) & & & & $\begin{array}{c}6.392 * * * \\
(1.249)\end{array}$ \\
\hline Constant & $\begin{array}{c}72.76^{* * *} \\
(0.810)\end{array}$ & $\begin{array}{c}67.07 * * * \\
(0.558)\end{array}$ & $\begin{array}{c}72.23 * * * \\
(0.767)\end{array}$ & $\begin{array}{c}68.01^{* * *} \\
(1.252)\end{array}$ \\
\hline Observations & 1,900 & 6,012 & 7,912 & 7,912 \\
\hline R-squared & 0.433 & 0.344 & 0.368 & 0.380 \\
\hline
\end{tabular}

Notes: The table reports OLS regression results clustered at the individual level. Column (1) and (2) report regression results disaggregated by phase, while table (3) and (4) report regression results run on the overall sample. Symbols *, **, *** denote significance at the 10, 5 and 1 percent level, respectively. 
Table 10: Heterogenous Treatment Effects

\begin{tabular}{|c|c|c|c|}
\hline VARIABLES & $\begin{array}{c}(1) \\
\text { bid_po }\end{array}$ & $\begin{array}{c}(2) \\
\text { bid_po }\end{array}$ & $\begin{array}{c}\text { (3) } \\
\text { bid_po }\end{array}$ \\
\hline Interaction term: & Income & Schooling & Sophistication \\
\hline Policy pays less per mm of deviation (mm) & $\begin{array}{c}-12.30 * * * \\
(0.794)\end{array}$ & $\begin{array}{c}-11.99 * * * \\
(0.683)\end{array}$ & $\begin{array}{c}-7.375^{* * *} \\
(0.631)\end{array}$ \\
\hline More likely policy pays maximum amount (exit) & $\begin{array}{c}11.71^{* * *} \\
(0.365)\end{array}$ & $\begin{array}{c}10.66^{* * *} \\
(0.341)\end{array}$ & $\begin{array}{c}7.868 * * * \\
(0.331)\end{array}$ \\
\hline Policy is from a distant rainfall station (basis risk) & $\begin{array}{c}-30.65 * * * \\
(1.061)\end{array}$ & $\begin{array}{c}-28.86 * * * \\
(0.926)\end{array}$ & $\begin{array}{c}-18.70 * * * \\
(0.824)\end{array}$ \\
\hline Phase 2 policy & $\begin{array}{c}-5.050 * * * \\
(0.862)\end{array}$ & $\begin{array}{c}-4.862 * * * \\
(0.882)\end{array}$ & $\begin{array}{c}-4.584 * * * \\
(0.864)\end{array}$ \\
\hline New Participants & $\begin{array}{c}6.328 * * * \\
(1.032)\end{array}$ & $\begin{array}{c}4.025^{* * * *} \\
(0.911)\end{array}$ & $\begin{array}{c}3.961^{* * *} \\
(0.868)\end{array}$ \\
\hline Ordering & $\begin{array}{c}-0.484 \\
(0.792)\end{array}$ & $\begin{array}{c}-0.443 \\
(0.797)\end{array}$ & $\begin{array}{c}-0.332 \\
(0.779)\end{array}$ \\
\hline Quartile II & $\begin{array}{l}1.947^{*} \\
(1.178)\end{array}$ & - & $\begin{array}{c}1.236 \\
(1.426)\end{array}$ \\
\hline Quartile III & $\begin{array}{c}2.692 * * \\
(1.343)\end{array}$ & $\begin{array}{l}0.0569 \\
(0.996)\end{array}$ & $\begin{array}{c}-4.063^{* * *} \\
(1.399)\end{array}$ \\
\hline Quartile IV & $\begin{array}{c}6.167^{* * *} \\
(1.415)\end{array}$ & $\begin{array}{l}2.053^{*} \\
(1.137)\end{array}$ & $\begin{array}{c}-4.043^{* * *} \\
(1.369)\end{array}$ \\
\hline [Variable] $*$ mm & $\begin{array}{c}0.157 \\
(0.265)\end{array}$ & $\begin{array}{l}0.0502 \\
(0.356)\end{array}$ & $\begin{array}{c}-1.688 * * * \\
(0.248)\end{array}$ \\
\hline [Variable] * exit & $\begin{array}{c}-0.335 * * \\
(0.136)\end{array}$ & $\begin{array}{c}0.114 \\
(0.186)\end{array}$ & $\begin{array}{c}1.116^{* * *} \\
(0.107)\end{array}$ \\
\hline [Variable] $*$ basis risk & $\begin{array}{c}0.477 \\
(0.363)\end{array}$ & $\begin{array}{c}-0.341 \\
(0.483)\end{array}$ & $\begin{array}{c}-4.007 * * * \\
(0.326)\end{array}$ \\
\hline Constant & $\begin{array}{c}68.13^{* * *} \\
(1.307)\end{array}$ & $\begin{array}{c}70.80 * * * \\
(1.022)\end{array}$ & $\begin{array}{c}72.88 * * * \\
(1.370)\end{array}$ \\
\hline $\begin{array}{l}\text { Observations } \\
\text { R-squared }\end{array}$ & $\begin{array}{l}7,912 \\
0.381\end{array}$ & $\begin{array}{l}7,912 \\
0.374\end{array}$ & $\begin{array}{l}7,912 \\
0.402\end{array}$ \\
\hline
\end{tabular}

The table reports OLS regression results run on the entire sample, clustered at the individual level. Column (1) reports heterogeneous effects with respect to income, Column (2) reports heterogeneous effects with respect to the years of schooling, and Column (3) reports results with respect to financial sophistication, an index variable that aggregates self-reported levels of financial sophistication and insurance experience. Symbols *, **, *** denote significance at the 10, 5 and 1 percent level, respectively. 
Appendix Tabel A1: Sample Balancing - Panel A

\begin{tabular}{|c|c|c|c|c|c|}
\hline Variable & $\mathrm{N}$ & $\begin{array}{c}\text { Treatment } \\
\text { Mean } \\
\end{array}$ & $\begin{array}{c}\text { Control } \\
\text { Mean }\end{array}$ & Difference & $\begin{array}{cc}\begin{array}{c}\text { Robust p- } \\
\text { value }\end{array} & \begin{array}{c}\text { Significance } \\
\text { Level }\end{array} \\
\end{array}$ \\
\hline \multicolumn{6}{|l|}{ A. Demographic Characteristics } \\
\hline Household size & 1,479 & 5.32 & 5.38 & -0.06 & 0.60 \\
\hline Number of children 6 years old or younger & 1,479 & 0.19 & 0.20 & -0.01 & 0.72 \\
\hline Number of children 18 years old or younger & 1,479 & 1.67 & 1.72 & -0.05 & 0.49 \\
\hline Age of household head (Years) & 1,470 & 49.82 & 49.37 & 0.45 & 0.49 \\
\hline Highest level of schooling completed by household head (Years) & 1,479 & 3.62 & 3.77 & -0.15 & 0.54 \\
\hline Household head is unschooled (1 = "Yes") & 1,479 & 0.56 & 0.54 & 0.02 & 0.32 \\
\hline Household head able to read (1 = "Yes") & 1,479 & 0.42 & 0.44 & -0.02 & 0.37 \\
\hline Household head able to write (1 = "Yes") & 1,479 & 0.38 & 0.41 & -0.03 & 0.25 \\
\hline \multicolumn{6}{|l|}{ B. Savings and Credit } \\
\hline Total amount of savings, all sources (Rs.) & 1,479 & $22,092.54$ & $20,606.70$ & $1,485.84$ & 0.33 \\
\hline Amount of savings with bank or post office (Rs.) & 1,479 & $1,735.26$ & $1,413.18$ & 322.08 & 0.27 \\
\hline Amount of savings in cash at home (Rs.) & 1,479 & $1,831.83$ & $1,596.73$ & 235.10 & 0.16 \\
\hline Amount of savings in jewelry (Rs.) & 1,479 & $13,274.70$ & $13,396.47$ & -121.77 & 0.91 \\
\hline Amount of savings with SHG or other group (Rs.) & 1,479 & $2,185.75$ & 2,117.36 & 68.39 & 0.79 \\
\hline Amount of other savings (Rs.) & 1,479 & $3,065.01$ & $2,082.97$ & 982.04 & $0.10 *$ \\
\hline Total amount of credit owed, all sources (Rs.) & 1,479 & $41,319.89$ & 41,972.02 & -652.13 & 0.80 \\
\hline Amount of credit from bank (Rs.) & 1,479 & $21,168.34$ & $19,652.26$ & $1,516.08$ & 0.36 \\
\hline Amount of credit from family and friends (Rs.) & 1,479 & $6,810.36$ & $5,998.17$ & 812.19 & 0.42 \\
\hline Amount of credit from MFIs (Rs.) & 1,479 & 557.87 & 827.45 & -269.58 & 0.16 \\
\hline Amount of credit from moneylenders (Rs.) & 1,479 & $11,504.71$ & $14,000.27$ & $-2,495.56$ & 0.12 \\
\hline Amount of credit from other sources of credit (Rs.) & 1,479 & $1,278.60$ & $1,493.89$ & -215.29 & 0.42 \\
\hline \multicolumn{6}{|l|}{ C. Livestock and other Assets (as of June 2009) } \\
\hline Number of large animals owned, i.e. buffalos, cows and oxen & 1,479 & 2.22 & 2.29 & -0.07 & 0.64 \\
\hline Number of small animals owned, i.e. goats, sheep, chicken, pigs & 1,479 & 4.70 & 5.77 & -1.07 & 0.36 \\
\hline Total market value of livestock owned (Rs.) & 1,479 & 31,921.99 & $36,626.48$ & $-4,704.49$ & 0.12 \\
\hline House type: strong structure (1 = "Yes") & 1,479 & 0.54 & 0.55 & -0.01 & 0.65 \\
\hline House type: semi-strong structure (1 = "Yes") & 1,479 & 0.33 & 0.32 & 0.01 & 0.67 \\
\hline House type: weak structure (1 = "Yes") & 1,479 & 0.13 & 0.12 & 0.01 & 0.81 \\
\hline Number or rooms in the house & 1,479 & 2.62 & 2.65 & -0.03 & 0.72 \\
\hline Estimated value of the house if owned (Rs.) & 1,479 & $116,938.10$ & $117,345.52$ & -407.42 & 0.96 \\
\hline
\end{tabular}




\section{Appendix Tabel A1: Sample Balancing - Panel B}

\begin{tabular}{|c|c|c|c|c|c|c|}
\hline Variable & $\mathrm{N}$ & $\begin{array}{c}\text { Treatment } \\
\text { Mean }\end{array}$ & $\begin{array}{c}\text { Control } \\
\text { Mean }\end{array}$ & Difference & $\begin{array}{c}\text { Robust p- } \\
\text { value }\end{array}$ & $\begin{array}{c}\text { Significance } \\
\text { Level }\end{array}$ \\
\hline \multicolumn{7}{|l|}{ C. Livestock and other Assets (as of June 2009) contd. } \\
\hline Total area of agricultural land (Acres) & 1,479 & 5.44 & 5.29 & 0.15 & 0.59 & \\
\hline Estimated value of agricultural land (Rs.) & 1,479 & $558,433.69$ & $457,886.75$ & $100,546.94$ & 0.19 & \\
\hline Estimated value of non-agricultural land and other houses (Rs.) & 1,479 & $6,677.00$ & $10,614.82$ & $-3,937.82$ & 0.13 & \\
\hline \multicolumn{7}{|l|}{ D. Agricultural Investments } \\
\hline Total cultivated land (acres) - all crops during Kharif'08 & 1,479 & 4.38 & 4.24 & 0.14 & 0.50 & \\
\hline Total cultivated land (acres) - cash crops during Kharif'08 & 1,479 & 3.48 & 3.32 & 0.16 & 0.27 & \\
\hline Any land planted - cash crops during Kharif'08 (1 = Yes) & 1,479 & 0.92 & 0.92 & 0.00 & 0.66 & \\
\hline Total amount spent on inputs - all crops during Kharif'08 & 1,479 & $20,036.09$ & $20,114.60$ & -78.51 & 0.94 & \\
\hline Amount spent on hybrid seeds - all crops during Kharif'08 & 1,479 & 853.28 & 844.28 & 9.00 & 0.94 & \\
\hline Amount spent on improved seeds - all crops during Kharif'08 & 1,479 & $4,374.40$ & 4,355.82 & 18.58 & 0.96 & \\
\hline Amount spent on fertilizer - all crops during Kharif'08 & 1,479 & 3,286.97 & $3,266.50$ & 20.47 & 0.92 & \\
\hline Amount spent on manure - all crops during Kharif'08 & 1,479 & $2,073.28$ & 2,339.35 & -266.07 & 0.10 & \\
\hline Amount spent on irrigation - all crops during Kharif'08 & 1,479 & 119.64 & 181.66 & -62.02 & 0.18 & \\
\hline Amount spent on hiring tractor/other impl - all crops during Kharif'08 & 1,479 & $2,722.60$ & $2,634.53$ & 88.07 & 0.64 & \\
\hline Amount spent on manual labor - all crops during Kharif'08 & 1,479 & $5,027.87$ & 4,895.52 & 132.35 & 0.63 & \\
\hline Amount spent on bullock labor - all crops during Kharif'08 & 1,479 & $1,578.04$ & $1,596.94$ & -18.90 & 0.88 & \\
\hline Total amount spent on inputs - cash crops during Kharif'08 & 1,479 & $15,868.37$ & $15,922.89$ & -54.52 & 0.94 & \\
\hline Amount spent on hybrid seeds - cash crops during Kharif'08 & 1,479 & 454.99 & 427.08 & 27.91 & 0.61 & \\
\hline Amount spent on improved seeds - cash crops during Kharif'08 & 1,479 & $4,011.70$ & $3,969.40$ & 42.30 & 0.89 & \\
\hline Amount spent on fertilizer - cash crops during Kharif'08 & 1,479 & 2,283.97 & $2,301.64$ & -17.67 & 0.88 & \\
\hline Amount spent on manure - cash crops during Kharif'08 & 1,479 & $1,753.77$ & $1,928.40$ & -174.63 & 0.24 & \\
\hline Amount spent on irrigation - cash crops during Kharif'08 & 1,479 & 22.53 & 40.23 & -17.70 & 0.29 & \\
\hline Amount spent on hiring tractor/other impl - cash crops during Kharif'08 & 1,479 & $2,083.15$ & $1,960.07$ & 123.08 & 0.28 & \\
\hline Amount spent on manual labor - cash crops during Kharif'08 & 1,479 & 3,865.88 & $3,884.43$ & -18.55 & 0.93 & \\
\hline Amount spent on bullock labor - cash crops during Kharif'08 & 1,479 & $1,392.37$ & $1,411.64$ & -19.27 & 0.86 & \\
\hline
\end{tabular}

The table reports a randomization test run on the baseline sample, where each variable is tested for treatment assignment OLS estimation, robust standard errors. Symbols *, **, *** denote significance at the 10, 5 and 1 percent level, respectively. 
Household size

Number of children 6 years old or younge

Number of children 18 years old or younge

Age of household head

Highest level of schooling completed by household head

Household head is unschooled

Household head able to read

Household head able to write

Number of large animals owned, i.e. buffalos, cows and oxen

Number of small animals owned, i.e. goats, sheep, chicken, pigs

Total market value of livestock owned

Total amount of savings, all sources

Amount of savings with bank or post office

Amount of savings in cash at home

Amount of savings in jewelry

Amount of savings with SHG or other group

Amount of other savings

Total amount of credit owed, all sources

Amount of credit from bank

Amount of credit from family and friends

Amount of credit from MFIs

Amount of credit from moneylenders

Amount of credit from other sources of credit

House type: strong structure

House type: semi-strong structure

House type: weak structure

Number or rooms in the house

Estimated value of the house if owned

Total area of agricultural land owned

Estimated value of agricultural land

Estimated value of non-agricultural land and other houses

Total cultivated land - all crops during Kharif' $0 \subseteq$

Total cultivated land - all crops during Kharif'Oc

In which Kartis did farmer plant? - all crops during Kharif'0s

Total cultivated land - cash crops during Kharif'Os

Total cultivated land - cash crops during Kharif' 0 s

In which Kartis did farmer plant? - cash crops during Kharif'OS

Did farmer replant crop this Kharif? - cash crops during Kharif' 0 c

Did farmer abandon crop this Kharif? - cash crops during Kharif' 0 c

Total amount spent on inputs - all crops (excl. pesticides) during Kharif'0s

Total amount spent on inputs - all crops during Kharif'Os

Amount spent on hybrid seeds - all crops during Kharif' $0 \subseteq$

Amount spent on improved seeds - all crops during Kharif' $0 \subseteq$

Amount spent on fertilizer - all crops during Kharif' $0 \subseteq$

Amount spent on manure - all crops during Kharif' 09

Amount spent on pesticide - all crops during Kharif' 0 s

Amount spent on irrigation - all crops during Kharif' 0 c

Amount spent on hiring tractor/other impl - all crops during Kharif'os

Amount spent on manual labor - all crops during Kharif'OS

Amount spent on bullock labor - all crops during Kharif' 0

Total market value used for all crops during Kharif' 0 s

Total market value used for all crops during Kharif'09, inputs 1-5

Total market value used for all crops during Kharif'09, inputs 1-

Market value used of hybrid seeds - all crops during Kharif' 0 s

Market value used of improved seeds - all crops during Kharif'os

Market value used of fertilizer - all crops during Kharif' 0 c

Market value used of manure - all crops during Kharif' 0 s

Market value used of pesticide - all crops during Kharif' 0 s

Market value used of irrigation - all crops during Kharif' 0 c

Market value used of hiring tractor/other impl - all crops during Kharif' 0 s

Market value used of manual labor - all crops during Kharif'0c

Market value used of bullock labor - all crops during Kharif'0s

Total market value used for cash crops during Kharif' $0 \subseteq$

Total market value used for cash crops during Kharif'09, inputs 1-5

Market value used of hybrid seeds - cash crops during Kharif' 0 c

Market value used of improved seeds - cash crops during Kharif' 0 s

Market value used of fertilizer - cash crops during Kharif'oc

Market value used of manure - cash crops during Kharif'0s

Market value used of pesticide - cash crops during Kharif' 0 s

Market value used of hybrid seeds - cash crops during Kharif' $0 c$

Market value used of improved seeds - cash crops during Kharif'oc

Market value used of fertilizer - cash crops during Kharif' 0 c

Market value used of manure - cash crops during Kharif'os

Market value used of pesticide - cash crops during Kharif' $0 \subseteq$

Total cultivated land - all crops during Kharif'oع

Total cultivated land - cash crops during Kharif'0ع

Any land planted - cash crops during Kharif'08

Total amount spent on inputs - all crops during Kharif'oع

Amount spent on hybrid seeds - all crops during Kharif' $0 \varepsilon$

Amount spent on improved seeds - all crops during Kharif'0ع

Amount spent on fertilizer - all crops during Kharif' $0 \varepsilon$

Amount spent on manure - all crops during Kharif'08

Amount spent on irrigation - all crops during Kharif' $0 \varepsilon$

Amount spent on hiring tractor/other impl - all crops during Kharif'0\&

Amount spent on manual labor - all crops during Kharif'08

Amount spent on bullock labor - all crops during Kharif'0\&

Years

Years

Dummy (1 = "Yes")

Dummy (1 = "Yes")

Dummy (1 = "Yes")

Indian Rupees

Indian Rupees

Indian Rupees

Indian Rupees
Indian Rupees

Indian Rupees

Indian Rupees

Indian Rupees

Indian Rupees

Indian Rupees

Indian Rupees

ndian Rupees

Indian Rupees

Indian Rupees

Indian Rupees

Dummy (1 = "Yes")

Dummy (1 = "Yes")

Dummy (1 = "Yes")

Indian Rupees

Acres

Indian Rupees

Indian Rupees

Dummy ( $1=$ if $>0$ )

Dummy ( $1=$ if $>0$ )

Dummy (1 = "Yes")

Dummy (1 = "Yes")

Indian Rupees

Indian Rupees

Indian Rupees

Indian Rupees

Indian Rupees

Indian Rupees

Indian Rupees

Indian Rupees

Indian Rupees

Indian Rupees

Indian Rupees

Indian Rupees

Indian Rupees

Indian Rupees

Dummy $(1=$ if $>0)$

Indian Rupees

Indian Rupees

Indian Rupees

ndian Rupees

Indian Rupees

Indian Rupees

Indian Rupees

Indian Rupees

Indian Rupees

Indian Rupees

Indian Rupees

Dummy ( $1=$ if $>0$ )

Indian Rupees

Indian Rupees

Indian Rupees

Indian Rupees

Indian Rupees

Dummy $=1$ if $>0$

Dummy $=1$ if $>0$

Dummy $=1$ if $>0$

Dummy $=1$ if $>0$

Dummy $=1$ if $>0$

Acres

Acres

Dummy (1 = "Yes")

Indian Rupees

Indian Rupees

Indian Rupees

Indian Rupees

Indian Rupees

Indian Rupees

Indian Rupees

Indian Rupees

Indian Rupees
Indian Rupees 
Total amount spent on inputs - cash crops during Kharif'08 Amount spent on hybrid seeds - cash crops during Kharif' $0 \varepsilon$ Amount spent on improved seeds - cash crops during Kharif'0ع Amount spent on fertilizer - cash crops during Kharif' $0 \varepsilon$ Amount spent on manure - cash crops during Kharif'08 Amount spent on irrigation - cash crops during Kharif'o\&

Amount spent on hiring tractor/other impl - cash crops during Kharif' $0 \varepsilon$

Amount spent on manual labor - cash crops during Kharif'08

Amount spent on bullock labor - cash crops during Kharif'0ع

\section{Treatment}

Fertilizer Treatment

Log of number of years of schooling of household head

Log of total area of agricultural land owned (Acres)

Wealth index: principal component

St. dev. of expected yield ( $\mathrm{kg} / \mathrm{acre})$ of cash crops without fertilizer

Insurance Knowledge Index

Ever heard of rainfall insurance

Interaction term between Treatment and Wealth Index

Interaction term between Treatment and Tot amount of agricultural land ownec

Interaction term between Treatment and Household head can read

Interaction term between Treatment and log of years of schoolin

Interaction term between Treatment and St. dev. of expected yield

Interaction term between Treatment and Insurance Knowledge Index

Interaction term between Treatment and Ever heard of rainfall insurance

All bids, if Phase I $=1$

All bids, if Phase II $=1$

All bids

Bid: Actual policy

Bid: Policy more likely to pay maximum amount (exit

Bid: Policy pays less per mm shortfall (mm

Bid: Policy from distant rainfall station (basis risk

Policy pays less per mm of deviation (mm

More likely policy pays maximum amount (exit

Policy is from a distant rainfall station (basis risk

Phase 2 Policy

New Participants

Policy Ordering 2

Quartile II Income Distribution

Quartile III Income Distribution

Quartile IV Income Distribution

Interaction term between Income and More likely policy pays maximum amount (exit)

Interaction term between Income and Policy pays less per $\mathrm{mm}$ shortfall $(\mathrm{mm}$

Interaction term between Income and Policy is from a distant rainfall station (basis risk

Quartile II Schooling

Quartile III Schooling

Quartile IV Schooling

Interaction term between Schooling and More likely policy pays maximum amount (exit)

Interaction term between Schooling and Policy pays less per $\mathrm{mm}$ shortfall $(\mathrm{mm}$

Interaction term between Schooling and Policy is from a distant rainfall station (basis risk

Quartile II Financial Sophistication

Quartile III Financial Sophistication

Quartile IV Financial Sophistication

Interaction term between Financial Sophistication and More likely policy pays maximum amount (exit' Interaction term between Financial Sophistication and Policy pays less per mm shortfall (mm

Interaction term between Financial Sophistication and Policy is from a distant rainfall station (basis risk
Indian Rupees

Indian Rupees

Indian Rupees

Indian Rupees

Indian Rupees

ndian Rupees

Indian Rupees

Indian Rupees

Indian Rupees

Indian Rupees

Dummy $(1=$ "Yes")

Dummy (1 = "Yes")

$\log (1+$ yrs. of schooling of $\mathrm{HH})$

$\log (1+$ acres of agric. Land owned)

First component of PCA. Variables includes a dummy if the household owns a specific type of livestock, the log of the total value of livestock, a dummy if the household has any type of credit, a dummy if the household has any type of savings, the log of total amount of savings and credit, the house type, the number of rooms in the house, the total area of agricultural land, the log of the house value, the log of the land value, and the log of the value of other assets.

Each respondent reports minimum, maximum, mean and intermediate values (I and III quartiles) yield, given a set of assumptions. Calculate standard deviation

Assign one point per 'good' response to five questions that ask individuals to calculate if they would get a payout and how large that payout would be, given a set of assumptions. Insurance Knowledge Index is the sum of this score [0-5]

Dummy (1 = "Yes")

Treatment * Wealth Index

Treatment $* \log (1+$ agricultural land owned

Treatment * Household head can read

Treatment $* \log (1+$ years of schooling

Treatment * St. dev. of expected yielc

Treatment * Insurance Knowledge Index

Treatment * Ever heard of rainfall insurance

Indian Rupees

Indian Rupees

Indian Rupees

Indian Rupees

Indian Rupees

Indian Rupees

Indian R

Dummy (1 = "Yes")

Dummy $(1=$ "Yes")

Dummy $(1=$ "Yes")

Dummy (1 = "Yes")

Dummy (1 = Individuals not in the original sample

Dummy (1 = Ordering 2)

Dummy (1 = "Yes")

Dummy (1 = "Yes")

Dummy (1 = "Yes")

Income * Exit

Income $*$ mm

Income * Basis Risk

Dummy (1 = "Yes")

Dummy (1 = "Yes")

Dummy (1 = "Yes")

Schooling * Exit

Schooling * mm

Schooling * basis risk

Dummy (1 = "Yes"). The financial sophistication index is the aggregate score on three questions: self reported financial sophistication, self reported experience with insurance and self-reported ability to evaluate insurance

Dummy (1 = "Yes"). The financial sophistication index is the aggregate score on three questions: self reported financial sophistication, self reported experience with insurance and self-reported ability to evaluate insurance

Dummy ( 1 = "Yes"). The financial sophistication index is the aggregate score on three questions: self reported financial sophistication, self reported experience with insurance and self-reported ability to evaluate insurance

Financial Sophistication * exit

Financial Sophistication * mm

Financial Sophistication * basis risk 